\title{
INSENTIF PPH FINAL DITANGGUNG PEMERINTAH SELAMA PANDEMI COVID-19 BAGI UMKM YANG MEMILIKI PEREDARAN BRUTO TERTENTU
}

\author{
Erna Rahmawati \\ Direktorat Jenderal Pajak \\ Vita Apriliasari \\ Politeknik Keuangan Negara STAN
}

Email: rahmaerna13@gmail.com, vapriliasari@pknstan.ac.id

\section{INFORMASI ARTIKEL}

Diterima Pertama

[25 07 2021]

Dinyatakan Diterima

[24 08 2021]

KATA KUNCI:

Insentif Pajak, Pandemi COVID-19, UMKM

KLASIFIKASI JEL:

$\mathrm{H} 25$

\begin{abstract}
ABSTRAK
The COVID-19 pandemic has wreaked havoc on Indonesia's economy, including the MSME sector. Many MSMEs have seen a drop in revenue or have even gone out of business. The government provides fiscal cushions in the form of incentives for final PP 23 Income Tax borne by the government in order to save the sustainability of MSME actors. The use of these incentives, however, has not been optimal at the national level. This motivates the author to examine how incentive policies are implemented in DGT vertical agencies at the Small Tax Office level. This study employs a combination approach, with data collected via documentation and interviews. The findings revealed that the XYZ Small Tax Office's use of incentives is still inefficient. Several optimization efforts have been undertaken, including socialization, appeals, and AR-provided guidance. However, there are still barriers to using incentives. To make it easier for taxpayers to take advantage of this incentive, the author suggests that information about incentives be disseminated via SMS blast and that realization reporting be done directly on the web without having to upload csv files.
\end{abstract}

Pandemi COVID-19 telah memberikan dampak masif bagi sektor perekonomian Indonesia, tak terkecuali sektor UMKM. Banyak pelaku UMKM yang mengalami penurunan omset atau bahkan gulung tikar. Guna menyelamatkan keberlangsungan pelaku UMKM, pemerintah memberikan bantalan fiskal berupa insentif Pajak Penghasilan final PP 23 ditanggung pemerintah (DTP). Namun, pemanfaatan insentif tersebut secara nasional belum optimal. Hal tersebut mendorong penulis untuk meninjau pelaksanaan beleid insentif pada instansi vertikal DJP setingkat KPP Pratama. Penelitian ini menggunakan metode kombinasi dengan pengumpulan data melalui dokumentasi dan wawancara. Hasil penelitian menunjukkan bahwa pemanfaatan insentif di KPP Pratama XYZ masih belum optimal. Beberapa upaya optimalisasi telah dilakukan seperti sosialisasi, himbauan, serta pemberian panduan oleh AR. Namun, kendala pemanfaatan insentif masih timbul. Penulis merekomendasikan agar penyebaran informasi terkait insentif juga dilakukan melalui SMS blast serta pelaporan realisasi dapat dilakukan melalui web secara langsung tanpa mengunggah csv file sehingga lebih mempermudah Wajib Pajak dalam memanfaatkan insentif ini. 


\section{PENDAHULUAN}

\subsection{Latar Belakang}

Ibaratkan bunga yang mempunyai putik sebagai pelatuk perkembangannya, sebuah negara juga mempunyai bidang vital sebagai penggerak roda perekonomiannya. Fakta bahwa Usaha Mikro, Kecil, dan Menengah (UMKM) merupakan sektor penting bagi perekonomian Indonesia tentu tidak bisa diabaikan begitu saja. Sektor UMKM mampu memberikan sumbangsih tidak hanya bagi kehidupan sosial, tetapi juga bagi pemenuhan pundi-pundi kas negara. Hal tersebut sejalan dengan penjelasan Teten Masduki, Menteri Koperasi dan Usaha Kecil dan Menengah, bahwa hingga Oktober 2020, UMKM telah berperan sebagai salah satu penyangga perekonomian nasional (Kemen KUKM, 2020). Lebih dari 64 juta pelaku UMKM menyerap hingga 97 persen tenaga kerja Indonesia dan juga menyumbang hingga 60 persen Produk Domestik Bruto Indonesia (Kemen KUKM, 2020). Pencapaian tersebut diharapkan berlanjut dengan meningkatnya kontribusi UMKM terhadap ekspor dari yang sebelumnya 14 persen menjadi 18 persen pada akhir tahun 2020 (Nugraha, 2019).

Ekspektasi yang dibidik sedemikian rupa agar terealisasi pada akhir tahun 2020 diragukan keberhasilannya. Hal tersebut disebabkan pada awal tahun 2020, pandemi Corona Viruses Diseases-19 (COVID-19) telah berhasil menggegerkan dunia, termasuk Indonesia. Untuk merespons penyebaran pandemi COVID-19 dan menyelamatkan kesehatan masyarakat, pemerintah memberlakukan kebijakan social distancing sejak awal Maret 2020 yang menuntut masyarakat untuk menjaga jarak antar individu dan menjauhi kerumunan (Hadiwardoyo, 2020, dikutip dalam Kartiko, 2020). Tidak hanya itu, pemerintah secara resmi mengumumkan gerakan Pembatasan Sosial Berskala Besar (PSBB) dan himbauan agar masyarakat bekerja dari rumah (Soetjipto, 2020).

Kebijakan guna menghentikan penyebaran wabah COVID-19 tersebut nyatanya memberikan efek samping bagi sektor perekonomian, termasuk sektor UMKM. Marlinah (2020) berpendapat bahwa kebijakan social distancing dan PSBB mampu menghambat pertumbuhan bisnis pelaku UMKM, khususnya bagi mereka yang memerlukan ruang pamer atau promosi. Sejalan dengan pendapat tersebut, Soetjipto (2020) mengungkapkan bahwa social distancing dan PSBB yang berkelanjutan juga berdampak pada merosotnya pendapatan pelaku UMKM. Bahkan hingga bulan Mei 2020, ratusan pelaku UMKM telah mengakhiri usahanya (Soetjipto, 2020).

Sebagai sektor yang memegang peran vital, terancamnya keberlangsungan UMKM akibat dampak pandemi COVID-19 ini menyumbang guncangan pada perekonomian yang tidak dapat dihindarkan oleh pemerintah (Anderson et al., 2020, dikutip dalam Kartiko, 2020). Hal tersebut memaksa pemerintah agar segera bertindak dan turun tangan guna menyelamatkan perekonomian Indonesia agar tidak semakin terpuruk. Untuk meminimalkan efek buruk tersebut, pemerintah perlu mengimplementasikan paket kebijakan ekonomi berupa kebijakan keuangan, fiskal, dan moneter (Gourinchas, 2020, dikutip dalam Kartiko, 2020). Salah satu beleid fiskal yang diundangkan pemerintah yaitu pemberian stimulus berupa insentif pajak sebagaimana tertuang dalam Peraturan Menteri Keuangan (PMK) Nomor 86/PMK.03/2020 tentang Insentif Pajak untuk Wajib Pajak Terdampak Wabah Virus Corona sebagaimana telah diubah dengan (s.t.d.d.) PMK Nomor 110/PMK.03/2020. Dalam beleid tersebut, Wajib Pajak UMKM yang menjalankan kewajiban perpajakan berdasarkan Peraturan Pemerintah Nomor 23 Tahun 2018 (Wajib Pajak UMKM PP 23/2018) menjadi sasaran pemberian insentif yaitu berupa insentif Pajak Penghasilan (PPh) final berdasarkan Peraturan Pemerintah 23 Tahun 2018 ditanggung Pemerintah (PPh final PP 23 DTP).

Insentif PPh final PP 23 DTP tersebut mempunyai karakteristik unik dalam penerapannya. Pajak yang terutang ditanggung pemerintah (DTP) melalui penyediaan pagu anggaran pada Anggaran Pendapatan dan Belanja Negara (APBN) dalam bentuk subsidi pajak. Dalam perhitungannya, anggaran negara akan tetap karena nilai DTP akan dicatat sebagai penerimaan perpajakan sekaligus dicatat sebagai pengeluaran berupa subsidi pajak dengan jumlah yang sama (Hartini, 2009). Berdasarkan penjelasan tersebut, dapat dipahami bahwa pemanfaatan insentif pajak DTP ini akan diperhitungkan sebagai penerimaan Direktorat Jenderal Pajak (DJP) seolah-olah terdapat pembayaran pajak dengan syarat insentif tersebut berhasil diterapkan.

Fakta terkait penerapan insentif secara nasional menunjukkan bahwa penggelondongan anggaran insentif PPh final PP 23 DTP sampai dengan 14 Oktober 2020 baru mencapai 460 miliar rupiah. Sudarso, Direktur Pelaksanaan Anggaran Direktorat Jenderal Perbendaharaan, menyampaikan bahwa realisasi tersebut hanya sebesar $19 \%$ dari 2,4 triliun rupiah pagu yang telah dianggarkan (Kurniati, 2020). Hal tersebut menyiratkan bahwa masih sedikit antusiasme UMKM dan sedikit pula UMKM yang berhasil memanfaatkan insentif yang ada. Salah satu penyebab ketidakberhasilan pemanfaatan insentif PPh final PP 23 DTP, walaupun Wajib Pajak UMKM PP 23/2018 telah mendapatkan persetujuan pemanfaatan insentif dari DJP, yakni tidak disampaikannya laporan realisasi (Setiawan, 2020a).

Surat Edaran Direktur Jenderal Pajak Nomor 47/PJ/2020 tentang Petunjuk Pelaksanaan Peraturan Menteri Keuangan (PMK) Nomor 86/PMK.03/2020 s.t.d.d. PMK Nomor 110/PMK.03/2020 menegaskan bahwa insentif PPh final PP 23 DTP tidak dapat dimanfaatkan oleh Wajib Pajak apabila kewajiban penyampaian laporan realisasi tidak ditunaikan oleh Wajib Pajak yang bersangkutan. Direktur Penyuluhan, Pelayanan, dan Humas DJP mengatakan bahwa 
berdasarkan fakta di lapangan, kepatuhan para Wajib Pajak yang memanfaatkan insentif dalam menyampaikan laporan realisasi ternyata masih belum optimal (Setiawan, 2020b). Ketidakoptimalan tersebut tentu mampu berpengaruh pada keberhasilan beleid insentif yang dicanangkan pemerintah ini.

Tujuan adanya beleid insentif PPh final PP 23 DTP yaitu guna memberikan keringanan kepada Wajib Pajak UMKM PP 23/2018. Pemerintah memberikan apa yang disebut bantalan sosial dengan wujud pemberian insentif perpajakan (Anjaeni, 2020). Dengan pemanfaatan insentif PPh final PP 23 DTP tersebut, Wajib Pajak UMKM PP 23/2018 tidak perlu membayar pajak selama periode pemberlakuan insentif sehingga Wajib Pajak dapat mengalokasikan uang pembayaran pajak untuk pemenuhan kebutuhan usahanya (Redaksi DDTCNews, 2020).

Namun, melihat fakta-fakta secara nasional sebagaimana dijelaskan di atas, pemanfaatan insentif masih belum optimal. Selain itu, penelitian yang telah dilakukan oleh Marlinah dan Syahribulan (2020) mengungkapkan bahwa banyak Wajib Pajak UMKM PP 23/2018 yang belum memanfaatkan insentif pajak dikarenakan kurangnya pemahaman mereka terhadap kebijakan insentif perpajakan. Penelitian terdahulu tersebut meninjau pemanfaatan insentif PPh final PP 23 DTP dalam lingkup nasional. Hasil penelitian terdahulu yang menyatakan kurang optimalnya pemanfaatan insentif mendorong penulis untuk meninjau dan menganalisis realisasi pemanfaatan insentif PPh final PP 23 DTP dengan berfokus pada wilayah kerja unit vertikal DJP setingkat Kantor Pelayanan Pajak (KPP).

\subsection{Tujuan Penelitian}

Penelitian ini bertujuan untuk meninjau dan menganalisis tingkat pemanfaatan insentif PPh final PP 23 DTP, dampak pemanfaatan insentif PPh final PP 23 DTP terhadap penerimaan pajak, kendala yang ditemui dalam optimalisasi pemanfaatan insentif, serta upaya yang telah dilakukan DJP untuk meningkatkan pemanfaatan insentif PPh final PP 23 DTP.

\section{KERANGKA TEORI DAN PENGEMBANGAN HIPOTESIS}

\subsection{Usaha Mikro, Kecil, dan Menengah (UMKM)}

Prabowo (2020) mengibaratkan UMKM sebagai tulang punggung perekonomian nasional lantaran UMKM memegang peranan strategis yang berkaitan dengan kemaslahatan masyarakat umum. Definisi tersebut sejalan dengan penjelasan Rudjito (2003, dikutip dalam Prawiro, 2020) yang mendefinisikan UMKM sebagai bisnis yang memiliki peranan penting terhadap perekonomian Indonesia, baik karena kontribusinya terhadap lapangan kerja yang tercipta maupun kontribusinya terhadap jumlah lapangan usaha. Peranan penting yang diemban UMKM juga diuraikan oleh Primiana (2009, dikutip dalam Prawiro, 2020) yang mendefinisikan UMKM sebagai motor penggerak pembangunan Indonesia yang merupakan pengembangan empat kegiatan ekonomi utama (core business), yaitu: bisnis kelautan, bisnis pertanian, industri manufaktur, dan Sumber Daya Manusia (SDM). Ketiga definisi tersebut memandang UMKM dari sisi peranan vital yang diembannya.

Di sisi lain, Undang-Undang Nomor 20 Tahun 2008 (UU 20/2008) Tentang Usaha Mikro, Kecil, dan Menengah (UMKM) membagi pengertian UMKM menjadi tiga komponen. Tiga komponen tersebut yaitu usaha mikro, usaha kecil, dan usaha menengah yang dikategorikan berdasarkan kekayaan bersih dan penjualan tahunan. Kekayaan bersih merupakan total nilai aset/ kekayaan usaha yang telah dikurangkan dengan total nilai liabilitas/ kewajiban. Sementara itu, hasil penjualan tahunan merupakan hasil penjualan produk dan/ atau jasa selama satu tahun buku yang telah dikurangkan dengan biaya-biaya terkait (hasil penjualan bersih/ neto). Kriteria UMKM sesuai dengan UU 20/2008 dijelaskan oleh Tabel II.1.

Tabel II. 1 Kriteria UMKM berdasarkan UU 20 /2008

\begin{tabular}{|l|l|l|l|}
\hline No & \multicolumn{1}{|c|}{ Uraian } & $\begin{array}{c}\text { Kepemilikan kekayaan } \\
\text { bersih (tidak termasuk tanah } \\
\text { dan bangunan) }\end{array}$ & \multicolumn{1}{|c|}{ Penjualan tahunan } \\
\hline 1. & Usaha Mikro & Maksimal Rp50 juta & Maksimal Rp300 juta \\
\hline 2. & Usaha Kecil & $>$ Rp50 juta - Rp500 juta & $>$ Rp300 Juta - Rp2,5 miliar \\
\hline 3. & Usaha Menengah & Rp500 juta - Rp10 miliar & $>$ Rp2,5 miliar - Rp50 miliar \\
\hline
\end{tabular}

Sumber: Diolah dari UU 20/2008 (2021)

Seiring berjalannya waktu, perekonomian Indonesia mengalami perubahan sehingga peraturan perundangundangan pun harus ikut direformasi. Undang-Undang Nomor 11 Tahun 2020 tentang Cipta Kerja (UU Cipta Kerja) yang berlaku sejak 2 November 2020 telah mengubah beberapa ketentuan terkait kriteria UMKM. Ketentuan mengenai kriteria UMKM berdasarkan UU Cipta Kerja tersebut tertuang dalam aturan pelaksanaan UU Cipta Kerja, yaitu Peraturan Pemerintah Republik Indonesia Nomor 7 Tahun 2021 (PP 7/2021) tentang Kemudahan, Perlindungan, dan Pemberdayaan Koperasi dan Usaha Mikro, Kecil, dan Menengah. Berdasarkan PP 7/2021 Pasal 35 Ayat 1, UMKM diklasifikasikan berdasarkan modal usaha atau hasil penjualan tahunan seperti ditunjukkan Tabel II.2.

Tabel II. 2 Kriteria UMKM berdasarkan PP 7/2021

\begin{tabular}{|l|l|l|l|}
\hline No & \multicolumn{1}{|c|}{ Uraian } & $\begin{array}{c}\text { Modal usaha (tidak } \\
\text { termasuk tanah dan } \\
\text { bangunan) }\end{array}$ & \multicolumn{1}{|c|}{ Penjualan tahunan } \\
\hline 1. & Usaha Mikro & Maksimal Rp1 miliar & Maksimal Rp2 miliar \\
\hline 2. & Usaha Kecil & $\begin{array}{l}>\text { Rp1 miliar }- \text { Rp5 miliar } \\
\text { Rp5 miliar }- \text { Rp10 miliar }\end{array}$ & $>$ Rp2 miliar - Rp15 miliar \\
\hline 3. & Usaha Menengah & Rpiliar - Rp50 miliar \\
\hline
\end{tabular}

Sumber: Diolah dari PP 7/2021 (2021)

PP 7/2021 Pasal 36 menjelaskan lebih lanjut bahwa selain kriteria modal usaha dan hasil penjualan tahunan sebagaimana diuraikan Tabel II.2, untuk kepentingan 
tertentu, kementerian/lembaga dapat menggunakan kriteria lainnya. Kriteria tersebut yaitu omzet usaha, net asset, total pegawai, penerapan teknologi ramah lingkungan, total investasi, kandungan lokal, dan/atau insentif dan disinsentif berdasarkan kriteria masingmasing bidang usaha.

\subsection{Pemajakan atas Penghasilan UMKM di Indonesia}

Sistem perpajakan Indonesia menetapkan aturan khusus bagi Wajib Pajak UMKM yang mempunyai omzet hingga batasan tertentu. Ketentuan ini pertama kali dituangkan dalam Peraturan Pemerintah Nomor 46 Tahun 2013 (PP 46/2013) Tentang Pajak Penghasilan atas Penghasilan dari Usaha yang Diterima atau Diperoleh Wajib Pajak yang Memiliki Peredaran Bruto Tertentu yang berlaku mulai Masa Pajak Juli 2013. Pemerintah mengundangkan PP 46/2013 dalam rangka mempermudah pengadministrasian perpajakan, meningkatkan keterbukaan, dan memberikan wadah bagi masyarakat untuk lebih melibatkan diri dalam pembangunan Indonesia (Anita, 2015). Poin penting yang termuat dalam PP 46/2013 dijelaskan oleh Prabantari dan Ardiyanto (2017), bahwa Wajib Pajak UMKM yang memiliki omzet hingga 4,8 miliar rupiah dalam kurun waktu satu tahun pajak berhak menanggung beban pajak final sebesar $1 \%$ dari omzetnya dengan dasar catatan peredaran bruto setiap bulannya sehingga Wajib Pajak tidak perlu melakukan pembukuan.

Setelah PP 46/2013 diterapkan selama beberapa tahun, pemerintah membuat revisi peraturan perpajakan guna meningkatkan kepatuhan Wajib Pajak UMKM secara sukarela dengan menerapkan pengurangan tarif dari $1 \%$ berdasarkan PP 46/2013 menjadi $0,5 \%$ sesuai dengan ketentuan baru, yaitu Peraturan Pemerintah Nomor 23 tahun 2018 (PP 23/2018) (Djuhartono et al., 2019). PP 23/2018 ini diberlakukan mulai Masa Pajak Juli 2018. Christian (2019, dikutip dalam Suci et al., 2019) menjelaskan pokok-pokok penting yang diatur PP 23/2018 sebagai berikut:

1) Penggunaan tarif PPh final sebesar 0,5\% merupakan sebuah pilihan,

2) Terdapat batas waktu penggunaan tarif $0,5 \%$,

3) PP 23/2018 berlaku bagi Wajib Pajak UMKM yang memiliki peredaran bruto/ omzet maksimal 4,8 miliar rupiah,

4) Wajib Pajak UMKM tidak bisa menjalankan kewajiban perpajakan berdasarkan PP 23/2018 apabila Wajib Pajak mempunyai pajak terutang atau telah membayar pajak di luar negeri atas penghasilan dari luar Indonesia, Wajib Pajak orang pribadi berpenghasilan dari usaha jasa terkait dengan pekerjaan bebas, Wajib Pajak menanggung beban PPh final lainnya, dan Wajib Pajak mendapatkan penghasilan yang termasuk bukan objek pajak.
Sebagaimana penjelasan pokok-pokok penting ketentuan PP 23/2018 poin pertama di atas, Wajib Pajak UMKM berhak memilih menggunakan tarif $0,5 \%$ atau tarif pada umumnya. Hal tersebut dijelaskan pada PP 23/2018 Pasal 3 Ayat 2 yang menyatakan bahwa Wajib Pajak tidak dikenakan tarif PPh final PP 23/2018 ketika Wajib Pajak memilih untuk menjalankan kewajiban perpajakan sesuai dengan tarif yang tercantum pada Ayat 1 huruf a dan Ayat 2a Pasal 17 Undang-Undang Pajak Penghasilan (UU PPh) atau Pasal 31E UU PPh.

Ketika Wajib Pajak telah memilih menjalankan kewajiban perpajakan berdasarkan PP 23/2018, Wajib Pajak harus memperhatikan batas waktu penggunaan tarif 0,5\% yang diuraikan pada PP 23/2018 Pasal 5 Ayat 2 sebagai berikut:

a) Untuk Wajib Pajak orang pribadi, maksimal tujuh tahun pajak;

b) Untuk Wajib Pajak badan berbentuk Commanditaire Vennootschap (CV), firma, atau koperasi, maksimal empat tahun pajak; dan

c) Untuk Wajib Pajak badan berbentuk Perseroan Terbatas (PT), maksimal tiga tahun pajak.

Ketentuan jangka waktu tersebut diatur lebih lanjut pada Pasal 5 Ayat 2 yang menjelaskan bahwa jangka waktu berakhirnya PP 23/2018 terhitung sejak:

a) Tahun Pajak Wajib Pajak mendaftarkan diri, untuk Wajib Pajak yang mendaftarkan diri sejak PP 23/2018 diberlakukan; atau

b) Tahun Pajak berlakunya PP 23/2018 yaitu tahun 2018, untuk Wajib Pajak yang mendaftarkan diri sebelum PP 23/2018 diberlakukan.

Setelah pengenaan tarif $0,5 \%$ melewati batas waktu sebagaimana ditetapkan, Wajib Pajak tidak berhak lagi menjalankan kewajiban perpajakan berdasarkan PP 23/2018. Wajib Pajak akan dikenakan tarif sesuai dengan Pasal 17 atau Pasal 31E UU PPh atas penghasilannya (Andrew \& Sari, 2021).

\subsection{Insentif Pajak Ditanggung Pemerintah}

\subsubsection{Insentif Pajak}

Menurut Ayu (2020, dikutip dalam Andrew \& Sari, 2021) insentif pajak merupakan kemudahan yang diberikan pemerintah di bidang perpajakan kepada orang pribadi maupun badan guna meningkatkan kepatuhan dalam pelaksanaan kewajiban perpajakan baik saat ini maupun di masa mendatang. Adanya kemudahan bagi Wajib Pajak berkat pemberian insentif pajak ini sejalan dengan penjelasan Barry (2002, dikutip dalam Sitohang \& Sinabutar, 2020) yang mendefinisikan insentif pajak sebagai suatu bentuk fasilitas perpajakan berupa penurunan tarif pajak bagi Wajib Pajak yang memenuhi syarat tertentu untuk memperkecil beban pajak yang harus dibayarkan. Kemudahan yang didapatkan Wajib Pajak akan adanya insentif tidak hanya berwujud pengurangan tarif saja. Asson dan Zolt (2003:3, dikutip dalam Selvi \& Ramdhan, 2020) menguraikan insentif pajak sebagai bentuk kredit pajak tertentu atau pengurangan, pengecualian pengenaan 
pajak, pembebasan pajak, kewajiban pajak yang ditangguhkan atau pemberlakuan tarif khusus. Ketiga definisi terkait insentif pajak di atas merujuk pada upaya pemerintah dalam memberikan kemudahan bagi Wajib Pajak dengan menerapkan berbagai macam bentuk kebijakan insentif pajak yang ada.

Dalam pemberian insentif pajak, terkadang pemerintah mempunyai tujuan yang lebih besar selain untuk meringankan beban Wajib Pajak secara personal. Winardi (2011, dikutip dalam Hasibuan, 2016) menyebutkan insentif pajak dengan istilah taxation incentive yang merujuk pada pemberian stimulus kepada Wajib Pajak tidak hanya untuk memenuhi kepentingan finansial pemerintahan saja, tetapi juga demi kepentingan perkembangan ekonomi dalam bidang tertentu. Penjelasan tersebut menempatkan insentif pajak sebagai kebijakan yang mengutamakan kemaslahatan umum. Namun, bertolak dari definisi insentif pajak tersebut, insentif pajak juga dapat diartikan sebagai alat bagi pemerintah agar Wajib Pajak lebih tunduk pada program pemerintah. Hal tersebut dijelaskan oleh Sitohang dan Sinabutar (2020) bahwa Insentif pajak merupakan cara yang digunakan untuk menarik individu atau badan tertentu agar mendukung program atau kegiatan pemerintah dengan cara mengurangi atau membebaskan pajak tertentu.

OECD (2020, dikutip dalam Kartiko, 2020) menerbitkan panduan terkait penetapan kebijakan berupa stimulus fiskal (insentif pajak) guna menangani kegentingan ekonomi, salah satunya yaitu pemerintah harus mempertimbangkan secara hati-hati pemberian insentif pajak selama recovery phase dan juga harus mempertimbangkan ketepatan sasaran. Mekanisme yang perlu dilakukan oleh pemerintah untuk mencapai ketepatan sasaran pemberian insentif ini diungkapkan oleh Rosdiana (2018, dikutip dalam Safrina et al., 2019) bahwa penting bagi pemerintah untuk meninjau dan menganalisis beleid pemberian insentif pajak secara dinamis dan komprehensif, bukan hanya secara linear. Pendapat tersebut sejalan dengan penjelasan Setyawan (2018) bahwa sebagai unsur penting dalam belanja pajak, beleid insentif pajak harus melalui kajian yang komprehensif dan mendalam sehingga menghasilkan kebijakan yang terselektif, terstruktur, dan terukur yang mampu menciptakan services level playing field bagi sektor perekonomian.

Selain perlunya analisis secara mendalam terkait kebijakan pemberian insentif perpajakan, mekanisme lain agar insentif pajak dapat tepat sasaran yaitu dengan memanfaatkan Laporan Belanja Perpajakan. Laporan Belanja Perpajakan merupakan alat yang bermanfaat untuk mengevaluasi pemberian insentif pajak, termasuk untuk mengukur efektifitas dan efisiensi pemberian insentif, dengan harapan agar insentif pajak lebih tepat sasaran sehingga mampu menimbulkan multiple effect bagi perekonomian Indonesia (Setiawan, 2019, dikutip dalam Safrina et al., 2019).
Dari penjelasan insentif pajak sebagaimana dipaparkan di atas, penulis menarik kesimpulan bahwa insentif pajak merupakan bentuk kemudahan yang diberikan pemerintah kepada Wajib Pajak baik untuk perkembangan perekonomian maupun untuk menyukseskan program pemerintah. Pemerintah harus mempertimbangkan dengan matang pemberian insentif agar tepat sasaran.

\subsubsection{Insentif Pajak Ditanggung Pemerintah}

Insentif pajak mempunyai berbagai macam bentuk, salah satunya pengecualian pajak. Kebijakan pengecualian pajak dapat berwujud pemberian insentif pajak ditanggung pemerintah. Marlinah dan Syahribulan (2020) menjelaskan insentif pajak ditanggung pemerintah sebagai bentuk pembayaran pajak terutang oleh pemerintah melalui penetapan pagu anggaran pada APBN. Penjelasan insentif pajak ditanggung pemerintah tersebut senada dengan pemaparan Samsuar Said (2008, dikutip dalam Hartini 2009) pajak ditanggung pemerintah adalah pajak terutang yang ditanggung oleh pemerintah dengan cara mengalokasikan anggaran dalam bentuk pemberian subsidi pajak. Pada struktur APBN, nilai DTP akan dicatat sebagai penerimaan perpajakan sekaligus dicatat sebagai pengeluaran berupa subsidi pajak dengan nilai yang sama sehingga anggaran negara akan tetap (in-out). Samsuar Said (2008, dikutip dalam Hartini 2009) juga menambahkan bahwa pembayaran pajak tidak benar-benar dilakukan oleh pemerintah, tetapi melalui insentif pajak DTP, pemerintah memberikan keringanan pajak kepada Wajib Pajak yang menjadi sasaran pemberian insentif.

Sebagaimana definisi-definisi di atas, penulis menyimpulkan bahwa insentif pajak DTP merupakan insentif pajak di mana Wajib Pajak tidak perlu melakukan pembayaran pajak lantaran pajak terutang telah dibebankan pada APBN. Keberhasilan pemanfaatan insentif pajak DTP akan menjadi unsur penerimaan perpajakan pada struktur APBN.

\subsection{Pengaturan insentif PPh final PP 23 DTP di Indonesia}

Bagi Wajib Pajak UMKM yang menjalankan kewajiban perpajakan berdasarkan PP 23/2018 dan terdampak adanya pandemi COVID-19, pemerintah memberlakukan kebijakan insentif pajak dalam bentuk pajak ditanggung pemerintah. Ketentuan tersebut dituangkan dalam beleid PMK Nomor 44/PMK.03/2020 tentang Insentif Pajak untuk Wajib Pajak Terdampak Pandemi Corona Virus Disease 2019 yang berlaku untuk Masa Pajak April hingga Masa Pajak September 2020. Pada Masa Pajak Juli 2020, PMK Nomor 44/PMK.03/2020 dicabut dan digantikan dengan PMK Nomor 86/PMK.03/2020 sebagaimana telah diubah dengan (s.t.d.d) PMK Nomor 110/PMK.03/2020 tentang Insentif Pajak untuk Wajib Pajak Terdampak Pandemi Corona Virus Disease 2019. PMK Nomor 86/PMK.03/2020 s.t.d.d PMK Nomor 110/PMK.03/2020 
ini memperpanjang pemberlakuan insentif PPh final PP 23 DTP hingga Masa Pajak Desember 2020. Timeline pemberlakuan PMK terkait insentif PPh final PP 23 DTP pada setiap masa pajak selama tahun 2020 ditunjukkan oleh Gambar II.1.

Gambar II. 1 Timeline pemberlakuan ketentuan insentif PPh final PP 23 DTP

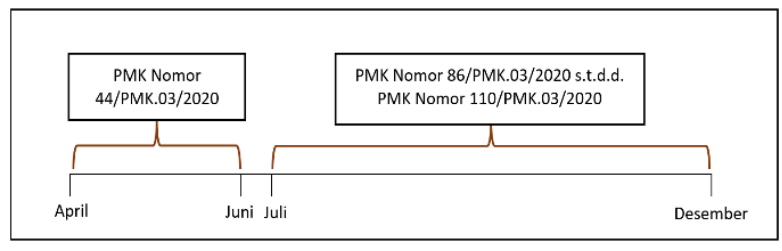

Sumber: Diolah dari PMK (2021)

Tujuan pemberian insentif pajak DTP ini diungkapkan dalam pertimbangan kebijakan PMK Nomor 44/PMK.03/2020 bahwa guna menanggulangi dampak COVID-19 yang memengaruhi stabilitas ekonomi dan produktivitas pelaku usaha, pemerintah perlu mengatur ketentuan terkait pemberian insentif pajak. Pemberian insentif pajak diperluas dengan mengikutsertakan Wajib Pajak yang mempunyai peredaran bruto tertentu sebagaimana diatur dalam PP 23/2018 (Wajib Pajak PP 23/2018) lantaran dampak pandemi yang telah meluas ke sektor UMKM. Sementara itu, pada pertimbangan kebijakan PMK Nomor 86/PMK.03/2020 s.t.d.d PMK Nomor 110/PMK.03/2020, tujuan beleid insentif pajak tidak hanya guna menanggulangi dampak COVID-19, tetapi juga memberikan kemudahan lebih terkait administrasi perpajakan bagi Wajib Pajak PP 23/2018 agar dapat memanfaatkan insentif.

Untuk mencapai tujuan terkait penanggulangan dampak COVID-19, pemberian insentif pajak DTP bagi Wajib Pajak UMKM yang menjalankan kewajiban perpajakan berdasarkan PP 23/2018 ditegaskan pada Pasal 5 Ayat 6 PMK Nomor 44/PMK.03/2020 dan Pasal 5 Ayat 3 PMK Nomor 86/PMK.03/2020 s.t.d.d PMK Nomor 110/PMK.03/2020 yang menyatakan bahwa PPh final berdasarkan PP 23/2018 ditanggung pemerintah. Ketentuan tersebut menghilangkan kewajiban Wajib Pajak PP 23/2018 untuk menanggung beban pajak sebesar $0,5 \%$ atas penghasilan usahanya, termasuk penghasilan yang bersumber dari transaksi dengan pemotong atau pemungut pajak.

Untuk mencapai tujuan terkait kemudahan administrasi perpajakan, PMK Nomor 86/PMK.03/2020 s.t.d.d PMK Nomor 110/PMK.03/2020 menyederhanakan prosedur pemanfaatan insentif pajak yang sebelumnya diatur dalam PMK Nomor 44/PMK.03/2020. Pasal 6 Ayat 1 PMK Nomor 44/PMK.03/2020 menjelaskan bahwa agar insentif PPh final PP 23 DTP dapat dimanfaatkan, Wajib Pajak PP 23/2018 harus mengajukan permohonan Surat Keterangan Wajib Pajak PP 23/2018 (SKET) terlebih dahulu melalui menu Konfirmasi Status Wajib Pajak (KSWP) pada akun DJP Online milik Wajib Pajak. Namun,
Pasal 6 Ayat 6 PMK Nomor 86/PMK.03/2020 s.t.d.d PMK Nomor 110/PMK.03/2020 menguraikan bahwa penyampaian laporan realisasi pemanfaatan insentif oleh Wajib Pajak PP 23/2018 pasca berakhirnya masa pajak akan diperlakukan sebagai pengajuan SKET. Penjelasan tersebut dapat dimaknai bahwa Wajib Pajak PP 23/2018 tidak diharuskan lagi mengajukan permohonan SKET sebelum memanfaatkan insentif pajak. Selain itu, PMK Nomor 86/PMK.03/2020 s.t.d.d PMK Nomor 110/PMK.03/2020 tidak mengatur adanya kewajiban bagi Wajib Pajak PP 23/2018 untuk melampirkan Surat Setoran Pajak (SSP) pada laporan realisasi sebagaimana sebelumnya diatur dalam Pasal 7 Ayat 5 PMK Nomor 44/PMK.03/2020.

Terkait transaksi dengan pemotong atau pemungut pajak, Pasal 5 Ayat 8 PMK Nomor 44/PMK.03/2020 dan Pasal 5 Ayat 6 PMK Nomor 86/PMK.03/2020 s.t.d.d PMK Nomor 110/PMK.03/2020 menjelaskan bahwa bagi Wajib Pajak yang menyerahkan fotokopi Surat Keterangan (SKET) kepada pemotong atau pemungut pajak dan SKET tersebut tervalidasi oleh Sistem Informasi DJP, tidak dilakukan pemotongan atau pemungutan PPh. Dengan adanya penjelasan tersebut, dapat dipahami bahwa syarat agar transaksi Wajib Pajak tidak dipotong atau dipungut pajak yaitu dengan menyerahkan fotokopi SKET kepada pemotong atau pemungut pajak.

Selain adanya hak bagi Wajib Pajak UMKM PP 23/2018 sehingga terhindar dari pembayaran pajak dan pemotongan atau pemungutan pajak, poin penting lainnya yang diatur pada PMK yaitu adanya kewajiban bagi Wajib Pajak UMKM PP 23/2018 untuk menyampaikan laporan realisasi PPh final PP 23 DTP. Mekanisme penyampaian laporan realisasi dijelaskan pada Pasal 6 PMK Nomor 44/PMK.03/2020 dan Pasal 6 PMK Nomor 86/PMK.03/2020 s.t.d.d PMK Nomor 110/PMK.03/2020 dengan poin intinya sebagai berikut:

a. Wajib Pajak harus mengunggah laporan realisasi PPh final PP 23 DTP melalui kanal www.pajak.go.id;

b. Laporan realisasi PPh final PP 23 DTP mencangkup seluruh nilai pajak terutang termasuk pajak yang timbul atas penghasilan dari pemotong atau pemungut pajak;

c. Pemotong atau pemungut pajak wajib menerbitkan cetakan kode billing atau SSP yang diberikan tulisan atau cap "PPh FINAL DITANGGUNG PEMERINTAH EKS PMK NOMOR .../PMK.03/2020" pada kolom uraian aplikasi pembuatan kode billing atau kolom uraian pembayaran SSP;

d. Laporan realisasi harus disampaikan oleh Wajib Pajak maksimal tanggal 20 masa pajak berikutnya.

Laporan realisasi menjadi tahapan vital dalam proses pemanfaatan insentif PPh final PP 23 DTP ini lantaran keberhasilan pemanfaatan insentif ditentukan oleh berhasil tidaknya penyampaian laporan realisasi. Surat Edaran (SE) DJP Nomor 29/PJ/2020 tentang Petunjuk Pelaksanaan PMK Nomor 44/PMK.03/2020 
dan SE DJP Nomor 47/PJ/2020 tentang Petunjuk Pelaksanaan PMK Nomor 86/PMK.03/2020 s.t.d.d PMK Nomor 110/PMK.03/2020 menegaskan bahwa insentif PPh final PP 23 DTP tidak dapat dimanfaatkan untuk masa pajak bersangkutan apabila Wajib Pajak tidak menyampaikan laporan realisasi. Ketidakberhasilan pemanfaatan insentif tersebut mengakibatkan timbulnya kewajiban penyetoran pajak terutang sebesar $0,5 \%$ dari omzet pada masa pajak yang tidak dilakukan penyampaian laporan realisasi.

Penjelasan di atas merupakan poin-poin penting pada PMK Nomor 44/PMK.03/2020 dan PMK Nomor 86/PMK.03/2020 s.t.d.d PMK Nomor 110/PMK.03/2020 serta aturan pelaksanaannya. Riwayat perbedaan peraturan dan juga pembaruan ketentuan antar PMK tersebut dijelaskan oleh Tabel II.3.

Tabel II. 3 Perbedaan dan Pembaruan Ketentuan Insentif PPh final PP 23 DTP

\begin{tabular}{|c|c|c|}
\hline No. & PMK & Perbaruan Ketentuan \\
\hline 1. & $\begin{array}{c}\text { PMK } \\
\text { Nomor } \\
\text { 44/PMK.03 } \\
\text { /2020 }\end{array}$ & $\begin{array}{l}\text { - Berlaku mulai Masa Pajak April } 2020 \text { hingga Masa Pajak } \\
\text { September } 2020 \text { (Pasal } 5 \text { Ayat 9) } \\
\text { - Mengajukan permohonan Surat Keterangan (Pasal } 6 \text { Ayat 1) } \\
\text { - Laporan realisasi disampaikan sepanjang Wajib Pajak telah } \\
\text { memiliki Surat Keterangan (Pasal } 7 \text { Ayat 3) } \\
\text { - Laporan realisasi dilampiri SSP (Pasal } 7 \text { Ayat 5) }\end{array}$ \\
\hline 2. & $\begin{array}{c}\text { PMK } \\
\text { Nomor } \\
86 / \text { PMK.03 } \\
/ 2020\end{array}$ & $\begin{array}{l}\text { - Berlaku mulai Masa Pajak April } 2020 \text { hingga Masa Pajak } \\
\text { Desember } 2020 \text { (Pasal } 5 \text { Ayat } 7 \text { ) } \\
\text { - Penyampaian Laporan Realisasi bagi Wajib Pajak yang belum } \\
\text { mempunyai Surat Keterangan dapat diperlakukan sebagai } \\
\text { pengajuan Surat Keterangan (Pasal } 6 \text { Ayat 6) } \\
\text { - Tidak ada kewajiban bagi Wajib Pajak PP 23/2018 untuk } \\
\text { melampirkan SSP pada laporan realisasi }\end{array}$ \\
\hline 3. & $\begin{array}{c}\text { PMK } \\
\text { Nomor } \\
110 / \text { PMK.0 } \\
3 / 2020\end{array}$ & $\begin{array}{l}\text { - Mempertegas ketentuan tidak diperlukannya penyampaian } \\
\text { kembali permohonan insentif pajak PP } 23 \text { DTP } \\
\text { - Mempertegas ketentuan bahwa Wajib Pajak tetap dapat } \\
\text { memanfaatkan insentif PPh final PP } 23 \text { DTP hingga akhir Masa } \\
\text { Pajak Desember }\end{array}$ \\
\hline
\end{tabular}

Sumber: Diolah dari PMK (2021)

Tabel II.3 merincikan ketentuan pemberian insentif PPh final PP 23 DTP selama tahun 2020. Sehubungan dengan masih dibutuhkannya insentif pajak bagi UMKM, pemerintah memperpanjang pemberlakuan insentif PPh final PP 23 DTP hingga Masa Pajak Juni 2021. Untuk menindaklanjuti perpanjangan pemberlakuan insentif tersebut, pada tanggal 2 Februari 2021, Pemerintah mengundangkan PMK Nomor 9/PMK.03/2021 tentang Insentif Pajak untuk Wajib Pajak Terdampak Pandemi Corona Virus Disease 2019. Dengan berlakunya PMK tersebut, PMK Nomor 86/PMK.03/2020 s.t.d.d PMK Nomor 110/PMK.03/2020 dicabut dan tidak berlaku lagi untuk Tahun Pajak 2021.

\subsection{Penelitian Terdahulu}

Sebelum penelitian ini dilaksanakan, terdapat penelitian-penelitian yang telah membahas topik terkait insentif pajak selama masa pandemi COVID-19. Berdasarkan penelitian yang dilakukan oleh Sitohang \& Sinabutar (2020), insentif pajak sudah diterapkan, tetapi belum optimal sehingga penerimaan yang diperoleh masih jauh dari pagu yang telah ditetapkan. Kesimpulan tersebut merupakan hasil penelitian terhadap seluruh jenis insentif yang diberikan selama pandemi COVID-19. Sementara itu, studi spesifik terkait insentif PPh final PP 23 DTP telah dilakukan oleh Sari et al. (2020) dengan hasil yang tidak berbeda, yaitu pemanfaatan insentif pajak selama masa pandemi COVID-19 belum optimal dikarenakan banyaknya Wajib Pajak UMKM yang belum memahami ketentuan perpajakan yang berlaku. Penyebab kurang optimalnya pemanfaatan insentif, yakni pemahaman UMKM yang masih rendah, juga disinggung dalam penelitian Marlinah dan Syahribulan (2020) yang mengungkapkan bahwa banyak UMKM yang belum memanfaatkan insentif pajak lantaran adanya kemungkinan bahwa pelaku UMKM masih belum memahami kebijakan insentif perpajakan yang diberikan. Penelitian Marlinah dan Syahribulan (2020) dilakukan dengan objek seluruh UMKM di Indonesia, sedangkan Sari et al. (2020) melakukan penelitian dengan objek UMKM di Kecamatan Ciracas, Jakarta Timur.

Selain ketiga penelitian terdahulu di atas, penelitian lainnya terkait dengan PPh final PP 23 DTP dilakukan oleh Andrew dan Sari (2021) yang menyimpulkan bahwa sosialisasi insentif, tarif pajak, pelayanan fiskus, dan batas waktu PP 23/2018 memberikan pengaruh terhadap kepatuhan Wajib Pajak UMKM, sedangkan sanksi perpajakan selama pandemi COVID-19 tidak memberikan pengaruh terhadap kepatuhan Wajib Pajak. Perbedaan penelitian yang dilaksanakan oleh Andrew dan Sari (2021) dengan ketiga penelitian terdahulu lainnya yaitu penelitian Andrew dan Sari (2021) menggunakan variabel penelitian yang lebih kompleks dan meninjau pengaruhnya terhadap kepatuhan Wajib Pajak UMKM. Sementara itu, penelitian terdahulu lainnya lebih meninjau keoptimalan penerapan insentif pajak.

Apabila dikomparasikan antara penelitian terdahulu sebagaimana disebutkan di atas dengan penelitian yang dilakukan penulis, penelitian ini berfokus pada PPh final PP 23 DTP dengan objek Wajib Pajak PP 23/2018 yang berada di wilayah kerja KPP Pratama XYZ. Selain itu, penelitian ini tidak hanya meninjau penerapan insentif saja, tetapi juga upaya optimalisasi pemanfaatan insentif serta pengaruh penerapan insentif terhadap penerimaan pajak KPP Pratama XYZ.

\section{METODE PENELITIAN}

\subsection{Desain penelitian}

Herdayati dan Syahrial (2019) menjelaskan bahwa desain penelitian adalah rancangan kegiatan pengumpulan, pengolahan, analisis, dan penyajian data yang dilakukan secara sistematis dan objektif. Guna mencapai tujuan penelitian, desain yang digunakan dalam penelitian ini adalah mixed methods dengan mengombinasikan metode kuantitatif dan metode kualitatif. Metode tersebut mampu memberikan jawaban yang lebih komprehensif daripada hanya menggunakan metode penelitian kuantitatif saja atau

Page $\mid 87$ 
metode penelitian kualitatif saja (Siahaan, 2016). Analisis deskripsi akan digunakan guna memperoleh gambaran lebih rinci mengenai pemanfaatan insentif PPh final PP 23 DTP pada instansi vertikal DJP pada tingkat KPP.

\subsection{Teknik Pengumpulan Data}

Pengumpulan data dilakukan dengan metode dokumentasi. Metode dokumentasi adalah cara yang diterapkan guna mendapatkan data dan informasi yang berwujud arsip, buku, dokumen, gambar dan tulisan angka yang berupa laporan, serta keterangan yang diperlukan guna mendukung penelitian (Sugiyono, 2015, dikutip dalam Warahmah, 2020). Penerapan teknik dokumentasi dalam penelitian ini diwujudkan dengan pencarian data-data perpajakan terkait insentif PPh final PP 23 DTP yang merupakan data sekunder. Data sekunder yang dikumpulkan berbentuk data terseleksi dan terkompilasi (compiled data) yang diperoleh dari Seksi Pengolahan Data dan Informasi KPP Pratama XYZ.

Selain metode dokumentasi, penulis juga menggunakan metode wawancara. Semi-structured interviews dipilih agar peneliti dapat mengeksplor informasi dengan tetap mengacu pada pertanyaan kunci yang telah dibuat sebelumnya. Wawancara dilakukan secara one-to-one dengan tiga orang narasumber masing-masing satu kali pelaksanaan. Pelaksanaan wawancara menggunakan media zoom meeting dengan durasi berkisar dua puluh hingga empat puluh lima menit sehingga hasil wawancara dengan tiga orang narasumber telah mencukupi kebutuhan penelitian. Rincian narasumber disajikan dalam Tabel III.1. Guna menjaga anonimitas identitas narasumber, pencantuman nama menggunakan inisial.

Tabel III. 1 Rincian Narasumber Penelitian

\begin{tabular}{|l|l|}
\hline Nama (Penyebutan) & \multicolumn{1}{|c|}{ Jabatan } \\
\hline DK (AR DK) & $\begin{array}{l}\text { Account Representative (AR) Seksi } \\
\text { Ekstensifikasi dan Penyuluhan }\end{array}$ \\
\hline ER (AR ER) & $\begin{array}{l}\text { AR Seksi Pengawasan dan } \\
\text { Konsultasi II }\end{array}$ \\
\hline YF (Pelaksana YF) & $\begin{array}{l}\text { Pelaksana Seksi Ekstensifikasi dan } \\
\text { Penyuluhan }\end{array}$ \\
\hline
\end{tabular}

Sumber: Diolah penulis (2021)

Narasumber penelitian sebagaimana ditunjukkan Tabel III.1 merupakan pegawai-pegawai yang berhubungan erat dengan pelaksanaan insentif PPh final PP 23 DTP. Narasumber pertama yakni AR DK. AR DK merupakan AR Seksi Ekstensifikasi Dan Penyuluhan yang menjadi pemandu dan pengawas pelaksanaan kewajiban perpajakan Wajib Pajak baru baik Wajib Pajak Orang Pribadi Usahawan, maupun Wajib Pajak Badan. Peran pemandu dan pengawas dilaksanakan AR DK termasuk terhadap pelaksanaan insentif PPh final PP 23 DTP. Pada saat penelitian ini dilakukan, AR seksi Ekstensifikasi dan Penyuluhan juga telah mengemban fungsi penggalian potensi sehingga lebih erat lagi interaksinya dengan Wajib Pajak. Tidak berbeda jauh dengan AR DK, AR ER juga merupakan pemandu dan pengawas pelaksanaan insentif perpajakan namun berada pada seksi yang berbeda, yakni Seksi Pengawasan dan Konsultasi II. Wajib Pajak yang ditangani AR ER lebih tergolong Wajib Pajak secara umum. Kedua AR tersebut dipilih sebagai narasumber guna menyumbang informasi antara lain terkait hal-hal yang mempengaruhi berhasil tidaknya Wajib Pajak PP 23/2018 dalam memanfaatkan insentif, dampak insentif terhadap penerimaan pajak KPP Pratama XYZ, kendala pemanfaatan insentif, serta upaya optimalisasi pemanfaatan insentif yang telah dilakukan KPP Pratama $\mathrm{XYZ}$.

Sementara itu, Pelaksana YF dipilih sebagai narasumber lantaran Pelaksana YF lekat dengan tugas penyuluhan, termasuk sosialisasi terkait insentif PPh final PP 23 DTP. Oleh karena itu, wawancara dengan AR YF ditujukan guna memberikan informasi terutama terkait upaya-upaya sosialisasi yang telah dilakukan KPP Pratama XYZ sehingga memengaruhi antusiasme Wajib Pajak PP 23/2018 dalam memanfaatkan insentif.

\section{HASIL PENELITIAN}

\subsection{Tingkat Pemanfaatan Insentif}

Sebagaimana tertuang dalam PMK Nomor 44/PMK.03/2020 dan PMK Nomor 86/PMK.03/2020 s.t.d.d PMK Nomor 110/PMK.03/2020, Wajib Pajak PP 23/2018 yang terdampak pandemi COVID-19 diberikan keringanan oleh pemerintah sehingga luruh kewajiban Wajib Pajak dalam menyetorkan PPh final PP 23. Penting bagi Wajib Pajak PP 23/2018 untuk mengetahui adanya kebijakan insentif PP 23/2018 ditanggung pemerintah ini lantaran terdapatnya kemudahan yang ditawarkan. Dengan memanfaatkan insentif tersebut, dana yang biasa digunakan oleh Wajib Pajak untuk membayar PPh final PP 23 setiap bulannya dapat dialokasikan untuk menjalankan aktivitas usahanya yang tengah tersendat akibat melemahnya perekonomian kala pandemi. Pentingnya pemahaman akan insentif ini disampaikan oleh AR DK dalam wawancara:

"Kalau yang namanya program sih sebenarnya, yang namanya program pemerintah ya, sebenarnya kita menginginkan seluruhnya itu tahu dan paham, tahu paham sekaligus nanti memanfaatkan insentif. Kenapa? karena dari pemerintah sendiri pun merasa ada tanggung jawab kepada UMKM. UMKM-UMKM yang ada di Indonesia ini kan sekarang lagi berkembang pesat. Nah, ini Pemerintah juga istilahnya merasa bertanggung jawab lah secara ekonominya, apakah mereka nanti bisa berjalan. E, daripada nanti digunakan untuk pembayaran pajak, inginnya pemerintah itu uang yang bisa dimanfaatkan Wajib Pajak dalam membayar pajak itu digunakan untuk transaksi. Inginnya pemerintah itu UMKM juga paham. Penting sekali untuk memahami dan memanfaatkan insentifnya, seperti itu." (10:02 WIB, 20/02/2021)

Walaupun keberadaan insentif ini bertujuan agar memudahkan Wajib Pajak PP 23/2018, AR DK menjelaskan bahwa pemanfaatan insentif PPh final bagi Wajib Pajak PP 23/2018 di wilayah kerja KPP Pratama 
XYZ masih belum optimal dan belum bisa dikatakan berhasil.

Berdasarkan data yang diperoleh dari pegawai seksi PDI KPP Pratama XYZ, dari 3.551 Wajib Pajak yang diidentifikasi sebagai Wajib Pajak PP 23/2018 berdasarkan jenis penyetoran pajaknya pada tahun 2020 , hanya $14 \%$ saja yang mengajukan insentif PPh final PP 23 DTP. Dengan kata lain, Wajib Pajak PP 23/2018 yang mengajukan insentif selama tahun 2020 hanya 504 Wajib Pajak. Jumlah tersebut merupakan akumulasi pengajuan insentif baik saat berlakunya PMK Nomor 44/PMK.03/2020 maupun ketika sudah dicabut dengan PMK Nomor 86/PMK.03/2020 s.t.d.d PMK Nomor 110/PMK.03/2020. Pengajuan insentif dilakukan dengan menyampaikan permohonan Surat Keterangan Wajib Pajak PP 23/2018 (SKET) untuk periode berlakunya PMK Nomor 44/PMK.03/2020 atau melaporkan realisasi pemanfaatan insentif pertama kali untuk periode berlakunya PMK Nomor 86/PMK.03/2020 s.t.d.d PMK Nomor 110/PMK.03/2020. Sementara itu, 86\% sisanya dari total 3.551 Wajib Pajak PP 23/2018 memilih untuk membayar PPh final PP 23 atau memilih untuk tidak memanfaatkan insentif. Perbandingan tersebut sebagaimana dipaparkan Gambar III.8.

Gambar III. 8 Tingkat Pengajuan Insentif PPh final PP 23 DTP

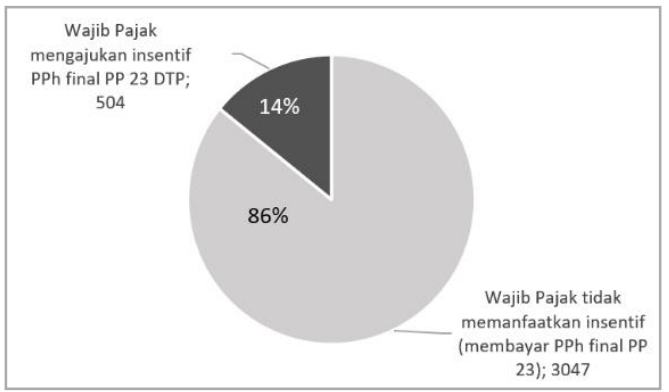

Sumber: Diolah dari Data Statistik KPP (2021)

Jumlah sebesar 504 Wajib Pajak PP 23/2018 yang mengajukan insentif tersebut belum tentu berhasil memanfaatkannya secara optimal karena Wajib Pajak tetap harus melaporkan realisasi pemanfaatan insentif untuk setiap masa pajak bersangkutan. AR DK menjelaskan bahwa laporan realisasi merupakan tahapan penting bagi Wajib Pajak karena menjadi syarat diakuinya pemanfaatan insentif. Selain itu, laporan realisasi yang mencantumkan peredaran usaha Wajib Pajak juga penting bagi pemerintah guna menjamin ketepatan sasaran pemberian insentif dan mencegah upaya penyalahgunaan oleh Wajib Pajak. Hal ini dipaparkan oleh AR DK dalam wawancara:

"Karena kan sebenarnya laporan itu kan salah satu cara pemerintah untuk menjamin ketepatan kan. Ketepatan pemanfaatan dan menghindari penyalahgunaan insentifnya. Bisa jadi yang memanfaatkan itu sebenarnya dia bukan kategori UMKM, kan bisa jadi seperti itu, tapi dia memanfaatkan ini, memanfaatkan insentif ini untuk istilahnya menghindari pajak. Kan gitu." (10:02 WIB, 20/02/2021)
Pernyataan AR DK tersebut sejalan dengan panduan OECD (2020, dikutip dalam Kartiko, 2020) bahwa dalam pemberian insentif selama recovery phase, pemerintah harus mempertimbangkan dengan hati-hati pemberian insentif. Ketentuan diwajibkannya laporan realisasi merupakan wujud pertimbangan pemerintah agar pemberian insentif tepat sasaran.

Selain pertimbangan ketepatan sasaran, laporan realisasi juga bentuk pertimbangan pemerintah agar insentif pajak DTP dapat dilaksanakan dengan membebankan pajak terutang pada belanja negara dalam APBN. Hal ini dijelaskan oleh AR ER:

"Makanya kalau di laporan realisasi kuncinya itu

ketika Wajib Pajak melakukan laporan realisasi,

Wajib Pajak itu, dia dianggap menggunakan, menggunakan insentif itu karena nilai yang dilaporkan di laporan realisasi itu nilainya nanti akan dianggap sebagai pengeluaran atau belanja negara, gitu. Kalau UMKM melapornya enggak nglapor, tapi dia memanfaatkan, ada lubang dong. Negara nggak bisa ngakuin sebagai belanja." (09:03 WIB, 28/02/2021)

Penjelasan kedua AR tersebut mempertegas bahwa laporan realisasi merupakan tahap vital bagi negara berkaitan dengan pengadministrasian insentif dan ketepatan sasaran serta tahap penting yang harus ditempuh Wajib Pajak PP 23/2018 agar berhasil memanfaatkan insentif.

Insentif PPh final PP 23 DTP berhasil dimanfaatkan oleh sebagian besar Wajib Pajak PP 23/2018 KPP Pratama XYZ yang mengajukan insentif. Dari 504 Wajib Pajak PP 23/2018 yang mengajukan insentif, sebanyak $80 \%$ atau 404 Wajib Pajak berhasil memanfaatkannya. Keberhasilan tersebut dilihat dari adanya pemanfaatan insentif oleh Wajib Pajak paling tidak untuk satu masa pajak melalui pengajuan SKET dan pelaporan realisasi saat PMK Nomor 44/PMK.03/2020 diberlakukan atau cukup melaporkan realisasi saja ketika berlaku PMK Nomor 86/PMK.03/2020 s.t.d.d PMK Nomor 110/PMK.03/2020. Sementara itu, selisihnya sebesar seratus Wajib Pajak tidak berhasil memanfaatkan insentif karena pada saat PMK Nomor 44/PMK.03/2020 diberlakukan, Wajib Pajak tersebut hanya mengajukan SKET tanpa menyampaikan laporan realisasi.

Lebih lanjut, berdasarkan tinjauan terhadap jenis Wajib Pajak, pengajuan insentif mayoritas dilakukan oleh Wajib Pajak Orang Pribadi, selanjutnya berturutturut disusul oleh CV, PT, dan terakhir Koperasi dengan total keseluruhan sebanyak 504 Wajib Pajak. Ketidakberhasilan pemanfaatan insentif sebanyak seratus Wajib Pajak yang hanya mengajukan SKET didominasi oleh Wajib Pajak Orang Pribadi dengan tingkat keberhasilan pemanfaatan insentif hanya sebesar $78 \%$. Selanjutnya, disusul oleh Wajib Pajak Badan berbentuk CV dengan tingkat keberhasilan mencapai $79 \%$ dan Wajib Pajak Badan berbentuk PT dengan tingkat keberhasilan $90 \%$. Sementara itu, Wajib Pajak Badan berbentuk Koperasi secara keseluruhan berhasil memanfaatkan insentif atau dalam hal ini Wajib Pajak tersebut tidak hanya mengajukan SKET, tetapi juga 
melaporkan realisasinya. Perbandingan jumlah Wajib Pajak yang mengajukan insentif dengan yang berhasil memanfaatkan insentif dipaparkan Tabel III.

Tabel III. 3 Perbandingan Jumlah Pengajuan Insentif dan Realisasi Insentif

\begin{tabular}{|c|c|c|c|c|}
\hline $\begin{array}{c}\text { Jenis Wajib } \\
\text { Pajak }\end{array}$ & $\begin{array}{c}\text { Jumlah yang } \\
\text { mengajukan } \\
\text { insentif }\end{array}$ & $\begin{array}{l}\text { Jumlah } \\
\text { realisasi }\end{array}$ & $\begin{array}{l}\text { Jumlah yang hanya } \\
\text { mengajukan SKET } \\
\text { tanpa laporan realisasi }\end{array}$ & $\begin{array}{c}\text { Persentase } \\
\text { keberhasilan }\end{array}$ \\
\hline & (a) & (b) & (a-b) & (b:a) \\
\hline Orang Pribadi & 305 & 239 & 66 & $78 \%$ \\
\hline PT & 59 & 53 & 6 & $90 \%$ \\
\hline $\mathrm{CV}$ & 131 & 103 & 28 & $79 \%$ \\
\hline Koperasi & 9 & 9 & 0 & $100 \%$ \\
\hline Total & 504 & 404 & 100 & $80 \%$ \\
\hline
\end{tabular}

Sumber: Diolah dari Data Statistik KPP (2021)

Pemberlakuan insentif PPh final PP 23 DTP selama tahun 2020 dapat dibagi menjadi dua periode. Pertama, periode berlakunya PMK Nomor 44/PMK.03/2020 selama Masa Pajak April hingga Masa Pajak Juni. Kedua, periode berlakunya PMK Nomor 86/PMK.03/2020 s.t.d.d PMK Nomor 110/PMK.03/2020 selama Masa Pajak Juli hingga Masa Pajak Desember yang mana terdapat penyederhanaan prosedur pemanfaatan insentif.

Selama masa berlakunya PMK Nomor 44/PMK.03/2020, jumlah penyampaian laporan realisasi terus mengalami kenaikan. Pada Masa Pajak Mei, pelaporan realisasi meningkat sebesar $7 \%$ atau terdapat penambahan 23 pelaporan. Peningkatan tersebut berlanjut pada Masa Pajak Juni dengan kenaikan 2\% atau terdapat penambahan enam pelaporan. Kondisi tersebut menunjukkan bahwa antusiasme Wajib Pajak PP 23/2018 dalam memanfaatkan insentif mengalami peningkatan selama berlakunya PMK Nomor 44/PMK.03/2020. Detail laporan realisasi insentif PPh final PP 23 DTP ditunjukkan Gambar III.9.

Gambar III. 9 Realisasi Pelaporan Insentif

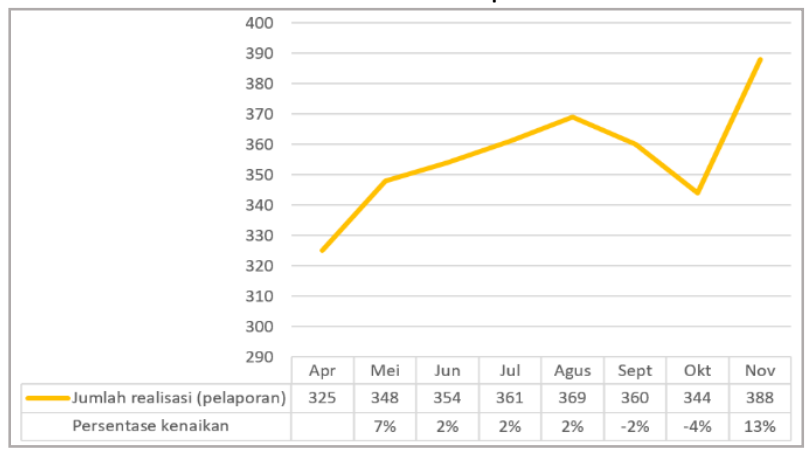

Sumber: Diolah dari Data Statistik KPP (2021)

Kemudian, ketika PMK Nomor 86/PMK.03/2020 s.t.d.d PMK Nomor 110/PMK.03/2020 diberlakukan selama Masa Pajak Juli hingga Masa Pajak Desember, jumlah pelaporan realisasi mengalami fluktuasi sebagaimana ditunjukkan Gambar III.9. Pada Masa Pajak Juli hingga Masa Pajak Agustus, jumlah pelaporan mengalami kenaikan secara konstan sebesar $2 \%$ yang mana persentase tersebut sama dengan kenaikan pelaporan pada Masa Pajak Juni ketika masih berlaku
PMK Nomor 44/PMK.03/2020. Kondisi tersebut menunjukkan bahwa pada saat awal diberlakukannya PMK Nomor 86/PMK.03/2020 s.t.d.d PMK Nomor 110/PMK.03/2020, penyederhanaan prosedur pemanfaatan insentif cenderung tidak diikuti dengan peningkatan yang signifikan atas pemanfaatan insentif yang ditunjukkan melalui penyampaian laporan realisasi.

Lebih lanjut, pada Masa Pajak September dan Masa Pajak Oktober pelaporan realisasi justru mengalami penurunan dengan persentase sebesar $-2 \%$ dan $-4 \%$. Penurunan tersebut menunjukkan bahwa antusiasme Wajib Pajak PP 23/2018 dalam melaporkan realisasinya mengendur. Namun, kenaikan signifikan justru terjadi pada Masa Pajak November dengan peningkatan pelaporan sebesar $13 \%$ yang mana menjadi masa pajak dengan jumlah pelaporan realisasi terbanyak selama Masa Pajak April hingga Masa Pajak November. Kenaikan jumlah pelaporan realisasi tersebut menunjukkan bahwa antusiasme Wajib Pajak PP 23/2018 dalam memanfaatkan insentif meningkat pada Masa Pajak November ini, baik antusiasme Wajib Pajak yang sebelumnya sudah mengajukan insentif maupun Wajib Pajak yang baru mengajukan insentif pada Masa Pajak November. Sementara itu, terkait pelaporan realisasi insentif Masa Pajak Desember, penulis belum mendapatkan data bersangkutan dari pegawai seksi PDI lantaran belum munculnya informasi tersebut pada sistem informasi.

Berdasarkan tinjauan terhadap keseluruhan pemanfaatan insentif PPh final PP 23 DTP selama tahun 2020, terdapat 404 Wajib Pajak berhasil memanfaatkan insentif sebagaimana diuraikan pada Tabel III.3 sebelumnya. Namun, jika meninjau realisasi pelaporan tiap bulannya sebagaimana ditunjukkan Gambar III.9, tidak ada pelaporan yang mencapai jumlah 404, paling banyak hanya 388 pelaporan pada Masa Pajak November. Hal tersebut membuktikan terdapatnya Wajib Pajak yang tidak rutin melaporkan pemanfaatan insentif setiap bulannya. Fakta tersebut juga didukung oleh data statistik sebagaimana dipaparkan Gambar III.9 sebelumnya bahwa pelaporan realisasi Masa Pajak September dan Masa Pajak Oktober mengalami penurunan. AR DK dalam wawancara juga memberikan penjelasan terkait kondisi ini:

"Kalau di data, data kepatuhan pelaporan ya, masih belum mencapai $100 \%$ juga. Nilainya masih kecilkecil juga, masih ada yang bolong-bolong pelaporannya, hanya lapor satu, dua bulan. Selebihnya tidak lapor sampai dengan sekarang, seperti itu juga masih beberapa." (10:02 WIB, 20/02/2021)

Berdasarkan penjelasan AR dan data statistik, pemanfaatan insentif PPh final PP 23 DTP masih belum optimal. Wajib Pajak yang mengajukan insentif baru $14 \%$ dari total Wajib Pajak PP 23/2018. Dari 14\% tersebut, hanya $80 \%$ saja yang benar-benar berhasil memanfaatkan insentif. Dengan demikian, selama tahun 2020, Wajib Pajak PP 23/2018 yang memperoleh benefit atas insentif ini hanya $12,8 \%$ dari keseluruhan Wajib Pajak PP 23/2018 atau 404 dari 3.551 Wajib Pajak 
sebagaimana ditunjukkan Gambar III.10. Dengan proporsi tersebut, pemanfaatan insentif oleh Wajib Pajak PP 23/2018 belum bisa dikatakan maksimal.

\section{Gambar III. 10 Proporsi Pengguna Insentif terhadap} Total Wajib Pajak PP 23/2018

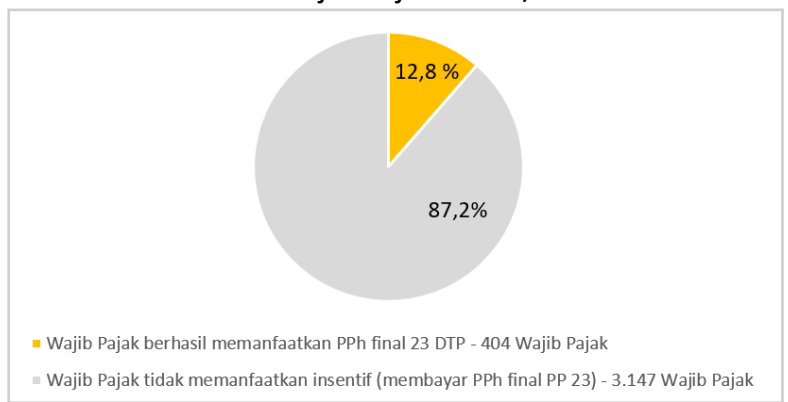

Sumber: Diolah dari Data Statistik KPP (2021)

\subsection{Dampak Pemanfaatan Insentif terhadap Penerimaan Pajak}

Berdasarkan penjelasan AR DK, nominal insentif PPh final DTP yang terealisasi akan dicatat sebagai penerimaan pajak sebagaimana karakteristik insentif pajak ditanggung pemerintah. Pencatatan sebagai penerimaan ini mempunyai tujuan jangka pendek, yaitu agar anggaran pada APBN bersifat tetap dengan mencatatkan nominal realisasi insentif pajak sebagai penerimaan perpajakan sekaligus sebagai belanja perpajakan pada struktur APBN.

Selain itu, pencatatan nominal realisasi insentif pajak DTP sebagai penerimaan juga memiliki tujuan jangka panjang, yakni guna memperkuat basis data perpajakan. Hal tersebut disampaikan AR DK bahwa pelaporan realisasi yang merupakan keharusan bagi Wajib Pajak akan digunakan sebagai catatan pemerintah terkait kemampuan (omzet) sesungguhnya dari Wajib Pajak yang bisa menjadi potensi pajak di masa mendatang. Wajib Pajak akan didorong untuk mengungkapkan omzet riil dari usahanya sehingga pemerintah akan mengetahui nominal penerimaan perpajakan yang sebenarnya secara makro (nasional). AR DK juga menambahkan penjelasan dalam wawancara:

"Kan biasanya ada juga Wajib Pajak yang penyetorannya itu sebenarnya tidak sesuai lah dengan ini, dengan apa, dengan omzet yang dilaporkan. Nah, dari situ kita juga bisa melihat ini sebenarnya kemampuan Wajib Pajak berapa. Kita sodorkan ada nih, ada insentif dari pemerintah, silahkan dimanfaatkan. Jadi, kita selain, e, menyukseskan program pemerintah, kita juga bisa mengedukasi Wajib Pajak. Silakan tidak dibayar dulu pajaknya tapi manfaatkan ini dan laporkan pajaknya dengan benar, seperti itu." (10:02 WIB, 20/02/2021)

Dengan demikian, pencatatan realisasi insentif sebagai penerimaan perpajakan mempunyai tujuan yang penting baik terkait pengadministrasiannya pada struktur APBN maupun berkenaan dengan penguatan basis data perpajakan. Tujuan penguatan basis data tersebut dapat tercapai apabila banyak Wajib Pajak yang memanfaatkan insentif dan melaporkan realisasi pemanfaatan insentif sesuai omzet sebenarnya.

Terkait dengan realisasi penerimaan pajak yang bersumber dari insentif PPh final PP 23 di KPP Pratama $X Y Z$, selama pemberlakuan insentif pajak dari Masa Pajak April hingga Masa Pajak November, nominal realisasi insentif berfluktuasi. Jika dibandingkan dengan jumlah pelaporan yang masuk sebagaimana ditunjukkan oleh Gambar III.9 sebelumnya, jumlah pelaporan yang meningkat tidak menjamin peningkatan nominal realisasi. Hal tersebut tercermin pada Masa Pajak Mei dan Juli yang mana jumlah pelaporan mengalami peningkatan masing-masing sebesar $7 \%$ dan $2 \%$ sementara nominal realisasi mengalami penurunan masing-masing sebesar $-8 \%$ dan $-10 \%$. Detail nominal realisasi ditunjukkan pada Gambar III.11.

Gambar III. 11 Nominal Realisasi Insentif PPh Final PP 23 DTP

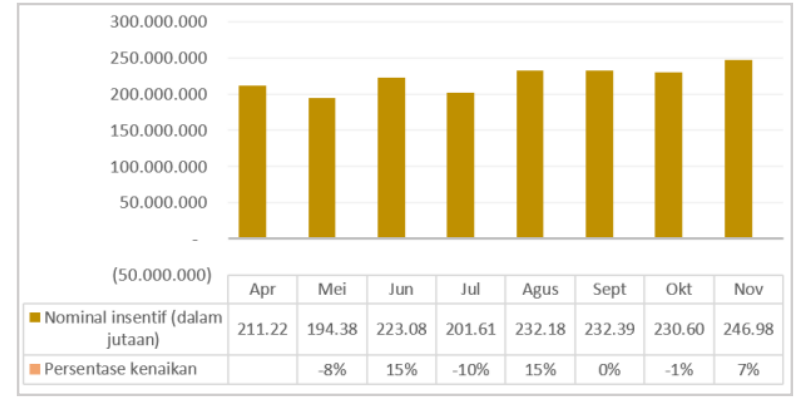

Sumber: Diolah dari Data Statistik KPP (2021)

Terkait dengan perbandingan kontribusi insentif PPh final PP 23 DTP terhadap total penerimaan PPh final PP 23/2018 di KPP Pratama XYZ, AR DK menyatakan bahwa pengaruh adanya insentif tersebut tidak begitu signifikan. Selama Masa Pajak April hingga Masa Pajak November tahun 2020, nominal realisasi insentif PPh final PP 23 DTP berkontribusi pada rentang $27 \%$ hingga $30 \%$ terhadap total penerimaan PPh PP 23/2018. Dari fakta tersebut, tampak bahwa lebih dari $70 \%$ penerimaan PPh PP 23/2018 berasal dari Wajib Pajak PP 23/2018 yang memilih menyetor pajaknya daripada mengambil keuntungan atas beleid insentif pajak ini. Detail penerimaan dari penyetoran PPh final PP 23/2018 dan penerimaan dari insentif PPh 23/2018 ditunjukkan Gambar III.12. 
Gambar III. 12 Total Penerimaan PP 23/2018 dan

Penerimaan dari Insentif PP 23/2018 DTP

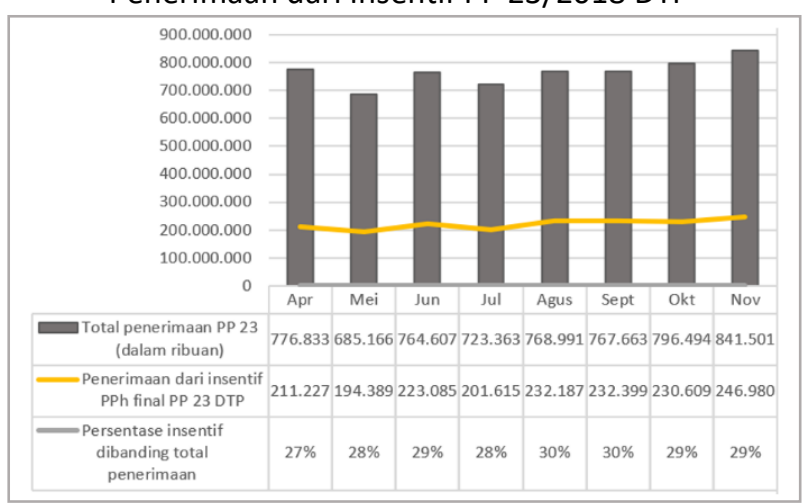

Sumber: Diolah dari Data Statistik KPP (2021)

Banyaknya penyetoran pajak oleh Wajib Pajak PP 23/2018 dikarenakan beberapa faktor. AR ER menyampaikan bahwa terdapat Wajib Pajak yang awalnya mengajukan permohonan Surat Keterangan Wajib Pajak PP 23/2018 guna memanfaatkan insentif PPh final PP 23 DTP, tetapi Wajib Pajak tersebut tidak menyampaikan laporan realisasi. Setelah dilakukan pengecekan, Wajib Pajak tersebut tidak melaporkan realisasi pemanfaatan insentifnya karena memutuskan untuk membayar pajak atau tidak mengambil benefit dari insentif tersebut.

Faktor lainnya yang menyebabkan penyetoran PPh final PP 23/2018 lebih mendominasi daripada penerimaan yang bersumber dari insentif dikarenakan pemanfaat insentif mayoritas Wajib Pajak kalangan menengah ke bawah. Fakta tersebut diungkapkan oleh AR DK:

"Yang memanfaatkan itu bukan Wajib Pajak - Wajib Pajak yang besar-besar itu, yang manfaatkan itu Wajib Pajak yang setorannya itu kategori yang bagian bawah lah. Jadi, untuk yang Wajib Pajak - Wajib Pajak yang besar itu mereka ya udahlah setor aja gitu daripada ribet untuk bikin laporan, mending setor aja kalau udah biasa, seperti itu sih, rata-rata seperti itu." (10:02 WIB, 20/02/2021)

\subsection{Kendala dalam Optimalisasi Pemanfaatan Insentif}

Program insentif PPh final PP 23 DTP merupakan kebijakan yang muncul dalam rangka merespons dampak pandemi COVID-19. Pelaksana YF menjelaskan bahwa untuk mengetahui adanya beleid tersebut dan memanfaatkannya, Wajib Pajak perlu meng-update informasi perpajakan. Namun, banyak Wajib Pajak PP 23/2018 yang kurang proaktif dalam mencari tahu adanya kebijakan pemerintah terkini. Beberapa Wajib Pajak PP 23/2018 berpandangan bahwa perpajakan hanya tentang kewajiban membayar pajak tanpa melihat adanya fasilitas-fasilitas yang menguntungkan dan bisa dimanfaatkan.

Sementara itu, ketika Wajib Pajak telah mengetahui adanya fasilitas dalam bentuk insentif pajak, Wajib Pajak dihadapkan dengan persoalan terkait pengetahuan adanya tindak lanjut pemanfaatan insentif, yakni penyampaian laporan realisasi. Kendala tersebut disampaikan oleh AR DK:

"Kalau kebanyakan (permasalahan) malah, "saya tidak tahu pak kalau ternyata harus dilaporkan, kalau harus ada laporan bulanan". Nah, itu loh yang jadi kendala itu. Sebenarnya itu jadi kendala utamanya sih di situ. Karena mereka juga dari awal cuma ngikut-ngikut aja, sudah dijelaskan di kantor, sampai rumah pun pasti juga karena tidak ini ya, tidak, tidak berkecimpung di situ, jadi tidak paham benar pada waktu diinformasikan. "Pak nanti setiap bulan lapor ya", "iya iya" aja, cuman kenyataan di lapangan, kenyataan setelah berjalannya waktu, mereka tidak ada penyampaian laporan realisasi, seperti itu." (10:02 WIB, 20/02/2021)

AR DK juga menambahkan bahwa banyak Wajib Pajak yang mengasumsikan pengajuan permohonan Surat Keterangan Wajib Pajak PP 23/2018 sebagai upaya terakhir yang akan membebaskan pembayaran pajaknya, tidak ada kewajiban tambahan yang perlu dilakukan. Oleh karena itu, Wajib Pajak tidak berhasil memperoleh insentif pajak DTP lantaran pelaporan realisasi tidak dilaksanakan.

Berikutnya, ketika Wajib Pajak telah mengetahui adanya kewajiban melaporkan realisasi insentif, Wajib Pajak dihadapkan dengan persoalan terkait sarana pelaporan dan tata cara penyampaian laporan realisasi. Laporan realisasi disampaikan secara daring melalui situs DJP Online yang membutuhkan sarana yang memadai dan pengetahuan lebih lanjut terkait tata cara pelaporannya. Namun, beberapa Wajib Pajak PP 23/2018 di lingkungan KPP Pratama XYZ terkendala media pelaporan dan banyak Wajib Pajak PP 23/2018 yang belum melek teknologi. AR DK menjelaskan:

"Kebanyakan Wajib Pajak UMKM itu tidak memiliki

komputer atau laptop sebagai sarana untuk pelaporan. Karena kan dipersyaratkan melaporkan dalam bentuk Excel ya, di-upload juga. Mereka pun rata-rata tidak ada yang memanfaatkan koneksi internet untuk itu. Mereka juga istilahnya dari pemahaman mereka pun juga belum maksimal, e, terus dari pengetahuan untuk menggunakan komputer laptop atau media lain yang dapat digunakan untuk laporan juga nggak maksimal. Jadi ya, kemungkinan kendala seperti itu." (10:02 WIB, 20/02/2021)

Selaras dengan penjabaran AR DK terkait adanya Wajib Pajak PP 23/2018 yang belum melek teknologi, Pelaksana YF mengungkapkan bahwa dengan pelaporan secara online, seharusnya Wajib Pajak dipermudah. Namun, karena inisiatif Wajib Pajak yang kurang dan terdapatnya Wajib Pajak yang belum melek teknologi, manfaat adanya insentif pajak ini terlewatkan.

Terkait permasalahan prosedur penyampaian laporan realisasi, AR ER menjelaskan secara spesifik berkenaan dengan kendala pengoperasian Excel (csv) yang perlu di-upload Wajib Pajak melalui akun DJP Online. Terdapat Wajib Pajak yang tidak memahami cara pengisian laporan realisasi sehingga nominal terlapor bukan peredaran usaha yang sebenarnya. AR ER mengungkapkan:

“. . . Wajib Pajak itu suka salah mengisi laporan realisasi. Di laporan realisasi ada 2 kotak, jadi tabel atas sama tabel bawah. Tabel atas tuh untuk 
pemanfaatan DTP yang dipotong sama lawan transaksi .... Nah, yang tabel kedua adalah yang disetor sendiri, tapi nggak disetor karena DTP kan jadi dia cuman laporan doang. Nah, atas dan bawah ini Wajib Pajak itu setelah dievaluasi isinya kembar atas bisa sejuta bawah sejuta berarti dia copas karena dia enggak ngerti. Akhirnya dievaluasi." (09:03 WIB, 28/02/2021)

Kendala yang dialami AR ER terkait dengan tidak pahamnya Wajib Pajak dalam mengoperasikan Excel tersebut serupa dengan persoalan yang ditemui AR DK. AR DK mengungkapkan bahwa Ketika Wajib Pajak mengajukan insentif, beberapa dari mereka tidak paham cara melaporkan realisasinya dan juga tidak tahu apa yang harus dilaporkan sehingga insentif gagal untuk dimanfaatkan.

Hasil penelitian yang mengungkap fakta bahwa pemanfaatan insentif di KPP Pratama XYZ belum optimal akibat ketidaktahuan Wajib Pajak PP 23/2018 akan adanya insentif pajak, kewajiban penyampaian laporan realisasi, dan prosedur pelaporan realisasi, serupa dengan penelitian sebelumnya. Penelitian Sari et al. (2020) dan Marlinah dan Syahribulan (2020) menarik kesimpulan yang sama bahwa kurangnya pengetahuan Wajib Pajak PP 23/2018 akan ketentuan perpajakan yang berlaku mengakibatkan belum optimalnya pemanfaatan insentif pajak selama masa pandemi COVID-19.

Pemanfaatan insentif yang belum optimal juga ditunjukkan dari banyaknya Wajib Pajak yang memilih membayar PPh PP 23/2018. Kewajiban penyampaian laporan realisasi yang membutuhkan media elektronik, koneksi internet, dan pemahaman kompleks terkait prosedur pelaporan membuat beberapa Wajib Pajak merasa kesulitan. Banyak dari mereka memutuskan untuk membayar pajaknya lantaran prosedur pelaporan dirasa kurang praktis. Namun, atas pembayaran tersebut, terdapat kemungkinan jika nominal yang dibayarkan oleh Wajib Pajak PP 23/2018 bukan berdasarkan peredaran usaha sebenarnya. Fakta tersebut diungkapkan oleh AR DK:

“. . . Wajib Pajak kadang gini daripada saya ribet untuk pelaporan mending saya bayar aja, gitu loh. Pada saat mereka bayar pun pasti nilainya itu tidak menyatakan yang sebenarnya, tidak dihitung berdasarkan nilai pajak yang sebenarnya, seperti itu. Nah itu yang rata-rata terjadi. Jadi, meskipun kita broadcast pun ya mereka ya tidak ada greget untuk, e, "Ya udah saya manfaatin", gitu nggak juga gitu loh. "Udah saya bayar aja daripada ribet untuk pelaporan, nanti pelaporan tiap bulan. Mending bikin kode billing langsung setor gitu aja udah selesai", rata-rata seperti itu." (10:02 WIB, 20/02/2021)

Sejalan dengan fakta tersebut, keberadaan insentif yang dimaksudkan untuk mempermudah Wajib Pajak justru dapat menjadi bumerang bagi beberapa Wajib Pajak PP 23/2018. Pelaporan realisasi yang membutuhkan media dan pengetahuan lebih dapat memunculkan beban administrasi yang nominalnya melebihi manfaat insentif yang akan diperoleh Wajib Pajak. AR ER menjelaskan:

". . . effort untuk bikin laporan realisasi sama effort untuk bayar, worth it mana itu. Kalau Mbak cuman bayar pajak cuman Rp15.000,00; Rp20.000,00; Rp25.000,00; mending Mbaknya bikin billing kan, daripada harus keluar waktu, uang juga untuk mungkin harus ke internet, harus minjam laptop orang, gitu." (09:03 WIB, 28/02/2021)

Dengan demikian, pertimbangan kepraktisan dan biaya administrasi lainnya menggiring Wajib Pajak untuk memilih menyetorkan PPh PP 23/2018.

Keputusan Wajib Pajak untuk menyetorkan pajak terutangnya mengakibatkan tidak maksimalnya pemanfaatan anggaran insentif pajak yang disiapkan pemerintah pada struktur APBN. Hal tersebut mendukung penelitian Sitohang dan Sinabutar (2020) bahwa penerimaan yang bersumber dari insentif pajak masih jauh dari pagu anggaran berupa belanja perpajakan (insentif pajak) yang telah ditetapkan pemerintah sehingga penerapan insentif belum dapat dikatakan optimal.

Selain kendala dari sisi Wajib Pajak sebagaimana dijelaskan di atas, kendala juga dialami oleh AR. Kendala personal yang dihadapi AR ketika mengoptimalkan program insentif ini yaitu sulitnya memandu Wajib Pajak secara langsung. Komunikasi melalui media elektronik tidak sepenuhnya berhasil dalam meningkatkan pemahaman Wajib Pajak terkait ketentuan dan prosedur pemanfaatan insentif. Hal tersebut diungkapkan oleh AR DK dalam wawancara:

"hambatannya ini sebenarnya dari interaksi dengan Wajib Pajak ya karena kondisi pandem ini kan Wajib Pajak juga terbatas untuk bisa ketemu dengan AR. Itu pasti sudah ada menjadi satu kendala. Komunikasi secara online itu masalahnya juga akan merepotkan, tidak sepenuhnya bisa dipahami sama Wajib Pajak itu. Kita jelaskan tidak sepenuhnya dia bisa paham apa yang dijelaskan kalau komunikasinya melalui online seperti ini, melalui telepon itu juga saya rasa tidak maksimal. Jadi, ya hambatan untuk sekarang ini ya karena interaksi dengan Wajib Pajaknya masih berjarak jadi agak susah, seperti itu sih." (10:02 WIB, 20/02/2021)

Kendala lainnya muncul terkait sistem yang digunakan untuk laporan realisasi, yakni DJP Online. Berdasarkan penjelasan AR ER, situs DJP Online sering lamban sehingga menghambat Wajib Pajak yang ingin melaporkan realisasi pemanfaatan insentifnya. Selain itu, AR ER juga mengungkapkan bahwa Wajib Pajak dapat meng-edit sesuka hati pelaporan yang telah disampaikan pada masa pajak sebelumnya yang dapat menjadi modus bagi Wajib Pajak untuk melaporkan nilai transaksi tidak berdasarkan keadaan sebenarnya.

\subsection{Upaya untuk Meningkatkan Pemanfaatan Insentif PPh Final PP 23 DTP}

Insentif PPh final PP 23 DTP merupakan kebijakan baru yang perlu disosialisasikan kepada Wajib Pajak PP 23/2018 agar dapat dimanfaatkan secara masif. Berdasarkan penjelasan AR DK, Kantor Pusat DJP menggencarkan sosialisasi terkait insentif ini melalui media cetak dan media elektronik. Selain itu, Kantor Pusat DJP juga mendelegasikan fungsi sosialisasi kepada unit vertikalnya, termasuk KPP. KPP diinstruksikan untuk 
memberikan informasi kepada Wajib Pajak agar memanfaatkan beleid insentif pajak ini.

Pelaksanaan sosialisasi insentif pajak di KPP Pratama XYZ dilakukan oleh Pegawai Seksi Ekstensifikasi dan Penyuluhan serta AR Wajib Pajak masing-masing. Sosialisasi oleh Pegawai Seksi Ekstensifikasi dan Penyuluhan dilakukan melalui pembentukan tim media sosial (medsos) untuk menyebarluaskan beleid insentif melalui berbagai macam social media milik KPP Pratama XYZ. Upaya tersebut disampaikan Pelaksana YF:

". . . penyuluhan di sini kan masih melekat ke Seksi Ekstensifikasi, jadinya untuk ... mensosialisasikan itu yang pertama, kita kan ada tim medsos, tim medsos itu memberikan informasi mengenai peraturan peraturan baru, e, yang ada, yang baru dikeluarkan atau yang ter-update itu ke umum. Tim medsos di sini untuk Instagram, Twitter itu, e, aktiflah untuk meng-update peraturan-peraturan tersebut agar dibaca ...." (16:22 WIB, 10/02/2021)

Sementara itu, AR KPP Pratama XYZ melakukan sosialisasi kepada masing-masing Wajib Pajak yang menjadi tanggung jawabnya melalui media Whatsapp dan media surat yang dikirimkan ke alamat Wajib Pajak, sebagaimana dijelaskan oleh AR DK:

". . . kita sudah menginformasikan kepada Wajib Pajak melalui WhatsApp, pasti kita pakai broadcast lah yang lebih mudah ya. Kita sudah punya nomor kontak masing-masing. kita broadcast ke mereka, yah rata-rata seperti itu. Kalau melalui surat juga ada, secara manual melalui surat juga ada, cuman pengirimannya tidak ke seluruh wajib pajak yang masuk dalam kategori UMKM." (10:02 WIB, 20/02/2021)

AR DK juga menambahkan bahwa tidak semua Wajib Pajak dikirimkan surat lantaran sasaran pengiriman surat mempertimbangkan Wajib Pajak PP $23 / 2018$ yang memiliki potensi besar dalam pembayaran pajak sehingga manfaat keberadaan insentif pajak ini akan lebih dirasakan oleh Wajib Pajak bersangkutan.

Setelah Wajib Pajak PP 23/2018 memperoleh sosialisasi dan memutuskan untuk mengambil insentif pajak DTP, Wajib Pajak harus melaporkan realisasi insentif yang dimanfaatkannya. Namun, banyak pula Wajib Pajak yang terlambat atau tidak menyampaikan laporan realisasi. Guna mengatasi kendala tersebut, berdasarkan penjelasan AR ER, Kantor Wilayah Jawa Timur III akan mengirimkan data Wajib Pajak yang belum lapor realisasi untuk dilakukan konfirmasi oleh AR dan memastikan apakah Wajib Pajak bersangkutan memanfaatkan insentif atau memilih untuk membayar pajaknya.

Setelah AR melakukan konfirmasi dan Wajib Pajak memilih untuk memanfaatkan insentif, AR menghimbau Wajib Pajak PP 23/2018 agar segera melaporkan realisasinya. Konfirmasi dan himbauan kepada Wajib Pajak dilakukan AR melalui berbagai media, seperti: SP2DK (Surat Permintaan Penjelasan atas Data dan/atau Keterangan) guna meminta konfirmasi, surat pemberitahuan agar Wajib Pajak melaporkan realisasi, media Whatsapp, dan sarana telepon. Jika Wajib Pajak mengalami kendala selama pelaporan, Wajib Pajak akan dibantu pelaporannya oleh AR. Hal tersebut diungkapkan oleh AR DK dalam wawancara:

"Yang pertama, kan pasti kita cek dulu seperti apa sih sebenarnya kondisinya Wajib Pajak ini. Selain nanti kita juga memberikan surat-surat istilahnya, surat pemberitahuan kembali bahwa saudara belum melaporkan loh untuk laporan insentif ini, bulan ini sampai dengan ini, silahkan segera dilaporkan, juga dari AR itu rata-rata langsung kontak ke Wajib Pajaknya melalui WhatsApp kah, melalui telepon $k a h$, untuk segera dikoordinasikan kendalanya yang sebenarnya apa, Wajib Pajak itu kendalanya apa, kalau by system gak bisa ya kita minta untuk datang ke kantor, kita sama-sama, kita bantuin untuk laporannya seperti apa yang sebenarnya, yang harusnya seperti apa, seperti itu." (10:02 WIB, 20/02/2021)

Upaya selanjutnya jika Wajib Pajak telah dihimbau untuk melaporkan realisasinya namun tidak kunjung lapor, AR akan menerapkan ketentuan peraturan perundang-undangan. Dalam SE DJP Nomor 29/PJ/2020 dan SE DJP Nomor 47/PJ/2020 ditentukan bahwa apabila Wajib Pajak PP 23/2018 tidak menyampaikan laporan realisasi, Wajib Pajak harus menyetorkan pajak terutangnya. Namun, hingga Masa Pajak Desember 2020, AR KPP Pratama XYZ tidak serta merta langsung menagihkan PPh PP 23/2018 kepada Wajib Pajak. AR masih mengupayakan agar Wajib Pajak melaporkan realisasinya untuk masing-masing masa pajak selama tahun 2020. AR DK mengungkapkan:

"Kalau selama ini tidak menyampaikan ya tadi disuratin lagi, cuman kalau di ketentuannya sih seharusnya mereka tidak berhak memanfaatkan untuk insentif itu tadi, cuma sampai dengan sekarang sih masih dalam tahap menginformasikan ke Wajib Pajak untuk melakukan pelaporan atau kalau memang sudah tidak ada, tidak ada pelaporan seperti ini, nanti dari $A R$, temen-temen $A R$ itu menerbitkan himbauan untuk penyetoran pajak yang terutang karena kan mereka sudah nggak berhak lagi untuk memanfaatkan insentif kan. Jadi, diterbitkan surat himbauan untuk penyetoran pajak sesuai dengan PP 23 biasa." (10:02 WIB, 20/02/2021)

Adanya kelonggaran lebih bagi Wajib Pajak PP 23/2018 berupa masih diberikannya kesempatan untuk menyampaikan laporan realisasi selama tahun 2020 merupakan upaya agar Wajib Pajak benar-benar dapat merasakan manfaat insentif ini.

Lebih lanjut, terkait sanksi yang melekat pada keterlambatan penyetoran pajak terutang lantaran Wajib Pajak PP 23/2018 tidak menyampaikan laporan realisasinya, AR tetap akan menagihnya, tetapi masih belum dilaksanakan. Penundaan penerbitan sanksi tersebut dikemukakan AR DK dalam wawancara:

“. . . untuk Surat Tagihan Pajak nanti kita kumpulkan dulu karena kan kita ngeceknya nanti keseluruhan ya, jadi langsung ada waktu kita mau menerbitkan STPnya, Surat Tagihan Pajak, nanti data sudah lengkap semuanya tidak satu per satu lagi. Nanti secara masal kita terbitkan." (10:02 WIB, 20/02/2021)

Sosialisasi dalam rangka menyebarluaskan beleid insentif dan pelayanan AR dalam memandu pelaporan realisasi Wajib Pajak PP 23/2018 merupakan upaya KPP Pratama XYZ yang berpengaruh terhadap kepatuhan Wajib Pajak di tengah pandemi COVID-19 ini. Hasil 
penelitian ini mendukung penelitian sebelumnya yang dilakukan Andrew dan Sari (2021) bahwa sosialisasi insentif dan pelayanan fiskus memberikan pengaruh terhadap kepatuhan Wajib Pajak UMKM.

\section{KESIMPULAN DAN SARAN}

Berdasarkan hasil penelitian terhadap unit vertikal DJP setingkat KPP Pratama, Pemanfaatan insentif PPh final PP 23 DTP di KPP Pratama XYZ masih belum optimal. Insentif PPh final PP 23 DTP hanya berhasil dimanfaatkan oleh 12,8\% Wajib Pajak PP 23/2018 atau 404 dari 3.551 Wajib Pajak. Pengaruh nominal realisasi terhadap total penerimaan PPh PP 23/2018 hanya sekitar 27\% hingga $30 \%$ pada masing-masing Masa Pajak April hingga Masa Pajak November 2020.

Terdapat beberapa kendala yang muncul dalam pelaksanaan insentif PPh final PP 23 DTP di KPP Pratama XYZ. Beberapa Wajib Pajak PP 23/2018 kurang proaktif dalam mencari tahu kebijakan perpajakan terkini sehingga Wajib Pajak tersebut tidak mengetahui keberadaan insentif pajak. Sementara itu, beberapa Wajib Pajak PP 23/2018 yang telah mengetahui keberadaan insentif tersebut tidak memahami adanya kewajiban lanjutan yang harus dilaksanakan berupa penyampaian laporan realisasi. Beberapa Wajib Pajak menganggap bahwa insentif pajak akan otomatis didapatkan ketika Wajib Pajak mengajukan permohonan SKET. Terkait kewajiban pelaporan realisasi, Kurangnya sarana pelaporan dan kompleksitas prosedur pelaporan memicu Wajib Pajak untuk tidak memanfaatkan insentif.

Selain kendala dari sisi Wajib Pajak, kendala juga muncul dari sisi AR. AR kesulitan memandu Wajib Pajak karena tidak mudah bagi Wajib Pajak untuk memahami ketentuan melalui penjelasan secara daring. Sementara itu, sistem administrasi insentif (DJP Online) guna pelaporan realisasi terkadang lamban. Sistem DJP Online juga memberikan peluang bagi Wajib Pajak untuk mengubah nilai transaksi pada laporan realisasi sehingga dapat menjadi modus penghindaran pajak.

Upaya optimalisasi telah dilakukan oleh KPP Pratama XYZ antara lain : (i) sosialisasi via media sosial oleh tim medsos, (ii) sosialisasi melalui media Whatsapp dan media surat oleh AR, (iii) konfirmasi serta himbauan oleh AR kepada Wajib Pajak untuk segera menyampaikan laporan realisasi, (iv) pemberian panduan oleh AR kepada Wajib Pajak dalam menyampaikan laporan realisasinya jika Wajib Pajak mengalami kendala, (5) diberikannya kesempatan kepada Wajib Pajak PP 23/2018 pada Masa Pajak Desember untuk melaporkan realisasi pemanfaatan insentifnya selama tahun 2020.

Dari upaya-upaya yang telah dilaksanakan KPP Pratama XYZ, beberapa kendala masih belum teratasi. Alternatif solusi guna mengantisipasi Wajib Pajak yang belum menggunakan Whatsapp dan guna memperbesar peluang Wajib Pajak UMKM mengetahui keberadaan insentif yakni dengan mensosialisasikannya melalui SMS blast. Selain itu, alternatif lainnya yakni penyederhanaan prosedur laporan realisasi dengan cukup melalui website menggunakan akun DJP Online milik Wajib Pajak tanpa prosedur peng-upload-an csv file, seperti pelaksanaan efiling SPT Tahunan. Pelaporan dengan cara tersebut dapat meminimalisasi kerumitan pengisian csv file sehingga lebih mempermudah Wajib Pajak.

\section{IMPLIKASI DAN KETERBATASAN}

Hasil penelitian ini diharapkan mampu menjadi bahan evaluasi atas penerapan kebijakan terkait pemberian insentif oleh DJP. Selain itu, penelitian ini juga diharapkan dapat menyumbang rekomendasi kebijakan dalam hal penyusunan strategi penyuluhan dan strategi pelaporan sehingga lebih efektif dan efisien. Rekomendasi strategi yang dimaksud yakni penyebaran informasi terkait insentif via SMS secara massal kepada Wajib Pajak dan pelaporan realisasi cukup melalui website DJP Online milik Wajib Pajak.

Pelaksanaan wawancara melalui zoom meeting mampu menghasilkan data yang memadai sebab para narasumber bersedia meluangkan cukup waktu guna pelaksanaan wawancara. Namun, kajian ini mempunyai keterbatasan terutama tidak diperolehnya data pemanfaatan insentif PPh final PP 23 DTP untuk Masa Pajak Desember. Keterbatasan tersebut mengakibatkan kurang mendalamnya pembahasan yang mungkin perlu diperhatikan untuk evaluasi lebih lanjut dan untuk pemberian rekomendasi yang lebih tepat guna.

\section{PENGHARGAAN (ACKNOWLEDGEMENT)}

Penulis mengucapkan banyak terima kasih kepada para dosen PKN STAN yang memberikan bimbingan serta arahan sehingga karya tulis ini dapat terselesaikan. Sebagaimana pepatah mengatakan "tak ada gading yang tak retak", begitu pula penyusunan karya tulis ini yang mungkin mengandung banyak kesalahan. Penulis bertanggung jawab penuh atas segala kesalahan dan kealpaan yang ada.

\section{DAFTAR PUSTAKA (REFERENCES)}

Andrew, R., \& Sari, D. P. (2021). Insentif PMK 86/2020 Di Tengah Pandemi Covid 19: Apakah Mempengaruhi Kepatuhan Wajib Pajak UMKM Di Surabaya? Jurnal Akuntansi Dan Pajak, 21(02), 349-366.

https://doi.org/10.29040/jap.v21i02.1597

Anita, T. (2015). Bagi Umkm Dalam Mempertahankan Keberadaan Umkm Di Indonesia. 7(3), 255-259.

Anjaeni, R. (2020). Sri Mulyani beberkan tujuan pemberian insentif bagi korporasi dan UMKM. Kontan.Co.Id. http://gg.gg/nkq2x

Batara Mulia Hasibuan. (2016). Sekilas Tentang Insentif Pajak. Binus University / Business Law. https://businesslaw.binus.ac.id/2016/10/17/sekilas-tentanginsentif-pajak/ 
DDTCNews, R. (2020). Paling Lambat Besok! Mau Pakai Insentif Pajak UMKM Hingga Desember? DDTC News. https://news.ddtc.co.id/paling-lambatbesok-mau-pakai-insentif-pajak-umkm-hinggadesember-23251?page_y=0

Djuhartono, T., Utami, A. A., Z. (2019). Analisis Kepatuhan Wajib Pajak UMKM atas Pemberlakuan PP 232018 Dibandingkan dengan PP 462013 (Studi Kasus UMKM Binaan Zaf Internasional). Sosio E-Kons, 11(3). https://journal.Ippmunindra.ac.id/index.php/sosi o_ekons/article/view/4528

Hartini. (2009). Analisis Manfaat Penurunan Tarif Pajak Penghasilan Orang Pribadi PPh Pasal 21 dan Insentif PPh Pasal 21 Ditanggung Pemerintah Tahun 2009 bagi Wajib Pajak. Diponegoro University | Institutional Repository (UNDIP-IR). http://eprints.undip.ac.id/24694/

Herdayati, \& Syahrial. (2019). Desain Penelitian dan Teknik Pengumpulan Data dalam Penelitian. ResearchGate.

https://www.researchgate.net/publication/3363 04206_DESAIN_PENELITIAN_DAN_TEKNIK_PENG UMPULAN_DATA_DALAM_PENELITIAN

Kartiko, N. D. (2020). Insentif pajak dalam merespons dampak pandemi covid-19 pada sektor pariwisata. Jurnal Pajak Dan Keuangan Negara, 2(1), 124-137.

Kurniati. (2020). Pemanfaatan PPh Final DTP Baru 19\%, Ini Realisasi Stimulus untuk UMKM. DDTC News. https://news.ddtc.co.id/pemanfaatan-pph-finaldtp-baru-19-ini-realisasi-stimulus-untuk-umkm24912?page_y=244

Marlinah, L. (2020). Peluang dan Tantangan UMKM Dalam Upaya Memperkuat Perekonomian Nasional Tahun 2020 Ditengah Pandemi Covid 19. Jurnal Ekonomi, 22(2), 118-124.

Menengah, K. K. dan U. K. dan. (2020). Sektor UMKM Jadi Kunci Pemulihan Ekonomi di Tengah Pandemi. http://www.depkop.go.id/read/sektorumkm-jadi-kunci-pemulihan-ekonomi-di-tengahpandemi

Nugraha, B. (2019). Kemenkop dan UKM Targetkan Peningkatan Kontribusi UMKM Terhadap PDB dan Ekspor.

https://www.suaramerdeka.com/ekonomi/pr04119137/kemenkop-dan-ukm-targetkanpeningkatan-kontribusi-umkm-terhadap-pdbdan-ekspor

Prabantari, F., \& Ardiyanto, M. (2017). IMPLEMENTASI PAJAK PENGHASILAN BERDASARKAN PERATURAN PEMERINTAH NOMOR 46 TAHUN 2013 (Studi pada UMKM di Jawa Tengah dan Daerah Istimewa Yogyakarta). Diponegoro Journal of Accounting, 6(4), 399-410.

Prabowo. (2020). Pengaruh Sebelum dan Sesudah Mendapatkan Pembinaan PLUT-KUKM terhadap Peningkatan Pendapatan Usaha Mikro Kecil
Menengah di Kabupaten Tulungagung. IAIN Tulungagung Institutional Repository. http://repo.iain-tulungagung.ac.id/16809/

Prawiro. (2020). Pengertian UMKM: Kriteria, Klasifikasi, Ciri-Ciri, dan Contoh UMKM. Maxmanroe.Com. https://www.maxmanroe.com/vid/bisnis/penger tian-umkm.html

Safrina, N., Soehartono, A., \& Savitri, A. (2019). Yang Berdampak Pada Penerimaan Pajak Di Indonesia Tahun 2019. 1, 1-11.

Sari, R. H. D. P., Darmastuti, D., Kirana, D. J., Wijayanti, A. (2020). Sosialisasi Insentif Pajak bagi Pelaku UMKM sebagai Dampak Pandemi COVID-19 di Kecamatan Ciracas Jakarta Timur. Repository UPN Veteran Jakarta. http://repository.upnvj.ac.id/8917/

Selvi, S., \& Ramdhan, A. (2020). Kajian Kebijakan Pemberian Insentif Pajak Dalam Mengatasi Dampak Virus Corona Di Indonesia Tahun 2019. Transparansi : Jurnal Ilmiah Ilmu Administrasi, 3(1), 96-100. https://doi.org/10.31334/transparansi.v3i1.846

Setiawan, D. A. (2020a). DJP Sebut 2 Faktor Ini Pengaruhi Rendahnya Insentif Pajak. DDTC News. https://news.ddtc.co.id/djp-sebut-2-faktor-inipengaruhi-rendahnya-insentif-pajak24491?page_y=1748

Setiawan, D. A. (2020b). Tidak Lapor Realisasi Insentif, Begini Dampaknya ke Wajib Pajak. DDTC News. https://news.ddtc.co.id/tidak-lapor-realisasiinsentif-begini-dampaknya-ke-wajib-pajak22520?page_y=805.3333129882812

Setyawan, H. (2018). Kebijakan Insentif Fiskal yang Mendorong Perekonomian. Komite Pengawas Perpajakan Kementerian Keuangan. http://www.komwasperpajakan.kemenkeu.go.id /Artikel/Details/1012

Siahaan, I. T. (2016). Metode Penelitian Kombinasi (Mixed Method). Kompasiana. https://www.kompasiana.com/vanwibo/58554d 385f23bdc8048b456a/metode-penelitiankombinasi-mixed-method

Sitohang, A., \& Sinabutar, R. (2020). ANALISIS KEBIJAKAN ISENTIF PAJAK DI TENGAH WABAH COVID-19 DI INDONESIA Alda Sitohang dan Romulo Sinabutar. Jurnal Ekonomi, 13, 14-25.

Soetjipto, N. (2020). Ketahanan UMKM Jawa Timur Melintasi Pandemi COVID-19. In K-Media.

Suci, T. S. M., Karamoy, H., Rondonuwu, S. (2019). Efektivitas Penerapan Peraturan Pemerintah No.23 Tahun 2018 Terhadap Tingkat Pertumbuhan Wajib Pajak dan Penerimaan PPh Final pada KPP Pratama Manado. Going Concern: Jurnal Riset Akuntansi, 14(23), 362-370. https://ejournal.unsrat.ac.id/index.php/gc/articl e/view/26289

Syahribulan, L. M. (2020). Peranan Insentif Pajak Yang Di Tanggung Pemerintah ( DTP ) Di Era Pandemi 
The Role of Government-Borne Tax Incentives in the Covid 19 Pandemic Era PENDAHULUAN Pandemi Covid 19 adalah sebuah epidemi yang telah menyebar ke berbagai negara atau benua, dan u. 2(2).

Warahmah, R. (2020). Tinjauan Pelaksanaan Program Inklusi Kesadaran Pajak Melalui Kegiatan Pajak Bertutur di Kota Makassar. Politeknik Keuangan Negara

STAN. https://drive.google.com/open ?id=1S6FWTQ_Ct uMNhVVtfUNY8vr_UuW-OxBr 